\title{
Protection, Openness and Factor Adjustment: Evidence from the manufacturing sector in Uruguay
}

\author{
Carlos Casacuberta (Universidad de la República) \\ Néstor Gandelman (Universidad ORT)
}

\begin{abstract}
This paper uses a panel of manufacturing firms to analyze the adjustment process in capital, blue collar and white collar employment in Uruguay during a period of trade liberalization when average tariff protection fell from 43 to 14 percent. Desired factor levels arising from a counterfactual profit maximization in the absence of adjustment costs are calculated, generating a measure of factor shortages or surpluses. The average estimated output gap for 1982-1995 is 2\%. Our policy analysis shows that trade openness affected the adjustment functions of all three factors of production. Highly protected sectors adjust less when creating jobs (reducing labor shortages) than sectors with low protection. This may be due to fears of policy reversal in highly protected sectors. Also, highly protected sectors adjust more easily (than low protection sectors) when destroying jobs (reducing labor surpluses), especially in the case of blue collar labor. This suggests that trade protection may in fact destroy rather than create jobs within industries, as firms in highly protected sectors are more reluctant to hire and more ready to fire than firms in sectors with low protection. The results for capital are qualitatively similar but quantitatively smaller, suggesting that trade protection plays less of a role in explaining adjustment costs for capital. Interestingly, export-oriented sectors have lower adjustment costs for blue collar labor, but not for white collar employment or capital, suggesting that export-led growth may be successful in reducing blue collar unemployment.
\end{abstract}

World Bank Policy Research Working Paper 3891, April 2006

The Policy Research Working Paper Series disseminates the findings of work in progress to encourage the exchange of ideas about development issues. An objective of the series is to get the findings out quickly, even if the presentations are less than fully polished. The papers carry the names of the authors and should be cited accordingly. The findings, interpretations, and conclusions expressed in this paper are entirely those of the authors. They do not necessarily represent the view of the World Bank, its Executive Directors, or the countries they represent. Policy Research Working Papers are available online at http:/lecon.worldbank.org.

\footnotetext{
* The authors thank Marcelo Olarreaga, Gabriela Fachola and participants at the 2005 Annual Meeting of the BCU for valuable comments. Fachola also helped with the database and the construction of the capital series. Financial support from the Word Bank Research Support budget is also gratefully acknowledged.
} 


\section{Introduction}

The traditional microeconomic textbook model assumes that the level of employment and capital used by firms is optimal at any point in time. But since adjusting employment and capital is costly to firms, they often deviate from what would be optimal in the absence of frictions. Understanding the way firms react to employment and capital shortages can shed light on many issues of microeconomic and macroeconomic nature. In this paper we analyze such adjustment process, based on a panel of manufacturing establishments in Uruguay.

The Uruguayan economy evolved from inward looking, based on state interventionism and import substitution protectionist policies, towards an outward looking orientation, with more reliance on markets as resource allocation mechanisms and exports as the growth engine. A first phase of trade reform took place in the 1970s, accompanied by a quick financial liberalization process. Later, trade liberalization was deepened in the 1990s, combining a gradual unilateral tariff reduction with the creation of Mercosur, an imperfect customs union between Argentina, Brazil, Paraguay and Uruguay.

A by-product of the trade liberalization process in Uruguay was that manufacturing firms switched to more capital intensive technologies. Specifically, in the 1990s, there were high job destruction rates as reported in Casacuberta, Fachola and Gandelman (2004). We focus on the adjustment process, and our main concern is with the effect of protection levels and trade liberalization on the adjustment functions for capital and white and blue collar employment.

The objectives of the paper are: i) to present an estimation of the adjustment functions for labor (blue and white collar) and capital, ii) to study the differences in the adjustment process for each factor of production and iii) to analyze the impact on these adjustment functions of tariff barriers, trade liberalization and international exposure.

Our main results confirm the lumpy and discontinuous nature of firms' adjustment process. Large shortages of one factor lead to less responsiveness in adjustment in the creation side of other factors but larger adjustment in the destruction side. Adjustment costs reduce the volatility of factor usage but on average they implied an annual gap between desired and observed output of $2 \%$. Less protected sectors adjust a larger fraction of the gap in the creation side but a lower fraction in the destruction side.

The paper proceeds as follows. Section 2 presents the policy experiments and the basic definitions of factor growth rates, factor shortages and adjustment functions. Shortages are defined with respect to some targeted desired levels. Section 3 details the methodology to obtain these desired levels. Readers not interested in the technicalities of this procedure may skip this section. Section 4 presents the results and analyzes the effects of policy changes in the adjustment process of firms and finally section 5 concludes. 


\section{Labor and capital adjustment functions}

In the traditional model without adjustment costs, the employment (capital) choice of the firms depends only on current shocks and future expectations. In the presence of adjustment costs, it also depends on past employment (capital) decisions and in the gap between the actual level of employment (capital) and the "desired" level. We will use the notation $B^{*}, W^{*}$ and $K^{*}$ and $B, W$ and $K$ for the desired and actual levels of blue collar labor, white collar labor and capital respectively. A key step in the present methodology is the construction of this "desired" level.

The growth rates of labor and capital inputs are defined as the ratio between the input changes and the averages between its past and present values. These definitions follow Davis and Haltiwanger (1992), and Davis et al (1996). ${ }^{1}$ Using the notation $\Delta$ for the rates of growth, we have

$$
\begin{gathered}
\Delta B_{\mathrm{jt}}=\frac{\mathrm{B}_{\mathrm{jt}}-\mathrm{B}_{\mathrm{jt}-1}}{\frac{1}{2}\left(\mathrm{~B}_{\mathrm{jt}}+\mathrm{B}_{\mathrm{jt}-1}\right)} \\
\Delta W_{\mathrm{jt}}=\frac{\mathrm{W}_{\mathrm{jt}}-\mathrm{W}_{\mathrm{jt}-1}}{\frac{1}{2}\left(\mathrm{~W}_{\mathrm{jt}}+\mathrm{W}_{\mathrm{jt}-1}\right)} \\
\Delta K_{\mathrm{jt}}=\frac{\mathrm{K}_{\mathrm{jt}}-\mathrm{K}_{\mathrm{jt}-1}}{\frac{1}{2}\left(\mathrm{~K}_{\mathrm{jt}}+\mathrm{K}_{\mathrm{jt}-1}\right)}
\end{gathered}
$$

Before a firm adjusts its factors of production, the employment (capital) shortage at time $t$ can be defined as the difference between the desired level of employment (capital) at time $t$ and the actual level at time $t-1$. Paralleling the previously defined growth rates, the shortage rate is expressed as a fraction of the average between the present desired level and the past observed level. Therefore, employment (blue and white collar respectively) and capital shortages $\left(Z B_{j t}\right.$, $\left.Z W_{j t}, Z K_{j t}\right)$ are:

\footnotetext{
${ }^{1}$ A feature of these growth rates is that they are bound between -2 and 2 . There is a monotonic relation between the rates of growth so defined and the usual ones.
} 


$$
\begin{aligned}
& Z_{\mathrm{jt}}=\frac{\mathrm{B}_{\mathrm{jt}}^{*}-\mathrm{B}_{\mathrm{jt}-1}}{\frac{1}{2}\left(\mathrm{~B}_{\mathrm{jt}}^{*}+\mathrm{B}_{\mathrm{jt}-1}\right)} \\
& Z W_{\mathrm{jt}}=\frac{\mathrm{W}_{\mathrm{jt}}^{*}-\mathrm{W}_{\mathrm{jt}-1}}{\frac{1}{2}\left(\mathrm{~W}_{\mathrm{jt}}^{*}+\mathrm{W}_{\mathrm{jt}-1}\right)} \\
& Z K_{\mathrm{jt}}=\frac{\mathrm{K}_{\mathrm{jt}}^{*}-\mathrm{K}_{\mathrm{jt}-1}}{\frac{1}{2}\left(\mathrm{~K}_{\mathrm{jt}}^{*}+\mathrm{K}_{\mathrm{jt}-1}\right)}
\end{aligned}
$$

Following Eslava et al (2005) adjustment functions $\left(A B_{j t}, A W_{j t}, A K_{j t}\right.$, for blue and white collar employment and capital, respectively) are defined as the fraction of each shortage that is actually closed. Hence adjustment functions are defined as follows:

$$
\begin{aligned}
& A B_{j t}=\frac{\Delta B_{j t}}{Z B_{j t}} \\
& A W_{j t}=\frac{\Delta W_{j t}}{Z W_{j t}} \\
& A K_{j t}=\frac{\Delta K_{j t}}{Z K_{j t}}
\end{aligned}
$$

The next step is to characterize such adjustment functions in terms of the shortages in all three factors. It is relevant to consider the case in which the adjustment function in each of them is not independent of the shortages observed in the other two. We follow a parametric strategy in which we allow capital and labor shortages to depend on their own shortage, on the other factors shortages and on interactive terms. In particular, the adjustment functions are not restricted to be linear and we allow for different intercept and slope for shortages and surpluses (or negative shortages). We do so because the causes of adjustment costs are different in the creation and destruction side. For instance, hiring new employees entails search, recruiting and training costs while firing current employees is associated with severance payments and eventual effects on the moral of the remaining employees. The basic specifications omitting the asymmetric interactions for positive shortages are: 


$$
\begin{aligned}
& A B_{j t}\left(Z B_{j t}, Z W_{j t}, Z K_{j t}\right)=\lambda_{0}+\lambda_{1} Z W_{j t}^{Z}+\lambda_{2} Z W_{j t} Z K_{j t}+\lambda_{3} Z W_{j t} Z B_{j t}+\lambda_{4} Z B_{j t}^{2}+\lambda_{5} Z B_{j t} Z K_{j t}+\lambda_{6} Z K_{j t}^{2} \\
& A W_{j t}\left(Z B_{j t}, Z W_{j t}, Z K_{j t}\right)=v_{0}+v_{1} Z W_{j t}^{Z}+v_{2} Z W_{j t} Z K_{j t}+v_{3} Z W_{j t} Z B_{j t}+v_{4} Z B_{j t}^{2}+v_{5} Z B_{j t} Z K_{j t}+v_{6} Z K_{j t}^{2} \\
& A K_{j t}\left(Z B_{j t}, Z W_{j t}, Z K_{j t}\right)=\kappa_{0}+\kappa_{l} Z W_{j t}^{2}+\kappa_{2} Z W_{j t} Z K_{j t}+\kappa_{3} Z W_{j t} Z B_{j t}+\kappa_{4} Z B_{j t}^{2}+\kappa_{5} Z B_{j t} Z K_{j t}+\kappa_{6} Z K_{j t}^{2}
\end{aligned}
$$

In practice, the estimated models are the following:

$$
\begin{gathered}
\Delta B_{j t}=Z B_{j t}\left[\lambda_{0}+\lambda_{1} Z W_{j t}^{2}+\lambda_{2} Z W_{j t} Z K_{j t}+\lambda_{3} Z W_{j t} Z B_{j t}+\lambda_{4} Z B_{j t}^{2}+\lambda_{5} Z B_{j t} Z K_{j t}+\lambda_{6} Z K_{j t}^{2}\right] \\
\Delta W_{j t}=Z W_{j t}\left[v_{0}+v_{1} Z W_{j t}^{2}+v_{2} Z W_{j t} Z K_{j t}+v_{3} Z W_{j t} Z B_{j t}+v_{4} Z B_{j t}^{2}+v_{5} Z B_{j t} Z K_{j t}+v_{6} Z K_{j t}^{2}\right] \\
\Delta K_{j t}=Z K_{j t}\left[\kappa_{0}+\kappa_{1} Z W_{j t}^{2}+\kappa_{2} Z W_{j t} Z K_{j t}+\kappa_{3} Z W_{j t} Z B_{j t}+\kappa_{4} Z B_{j t}^{2}+\kappa_{5} Z B_{j t} Z K_{j t}+\kappa_{6} Z K_{j t}^{2}\right]
\end{gathered}
$$

The significance of the non linear terms would indicate that a firm with a larger gap between desired and actual factor levels adjusts more, hence this would be evidence of the presence of fixed costs associated with adjustment. These fixed costs cause the adjustment decisions to be lumpy. In other words if there is lumpiness in the adjustment process, then the percentage of adjustment towards the desired levels for each factor is expected to be increasing in the absolute value of the shortage of that factor.

Our policy exercises will be framed in terms of an extended version of equation (5). We focus basically on tariff protection and trade reform. The first step is then to estimate pre and post Mercosur adjustment functions to detect shifts in the response of firms arising from changes in the environment. However, since this does not allow isolating the reform effect from other factors also present in the period, we also study the interactions of a set of policy variables with the adjustment functions. In our policy experiments we use tariffs, changes in tariffs, and a measure of export orientation of firms.

Finally, we find it useful to calculate the output gap attributable to adjustment costs. The output gap follows straightforward from the production function and the actual and desired input levels.

\section{Estimation of desired input levels}

A technical description of the methodology for the estimation of the desired input levels follows. The reader interested mostly in the results of our exercises may skip this section and proceed directly to section 4 . 


\subsection{Frictionless factor levels}

To obtain the firm's desired factor input levels, our procedure starts by estimating the firm's frictionless factor demands, based on prior estimates of plant level productivity and demand shocks. Estimating the frictionless input levels allows obtaining in turn the desired input levels. Frictionless levels correspond to those levels of inputs that the firm would choose in absence of adjustment costs, and are derived from the firm's optimization problem.

The firm's production function is assumed to be:

$$
Y_{j t}=K_{j t}^{\alpha}\left(B_{j t} H_{j t}\right)^{\beta} W_{j t}^{\mu} E_{j t}^{\gamma} M_{j t}^{\phi} V_{j t}
$$

where $K$ is capital, $B$ is blue collar employment, $H$ are blue collar hours, $W$ is white collar employment, $E$ is energy, $M$ are materials and $V$ is total factor productivity shock. ${ }^{2}$

There is also an inverse demand function for the firm, given by:

$$
P_{j t}=Y_{j t}^{-\frac{1}{\eta}} D_{j t}
$$

where $\eta$ is the elasticity of demand and $D$ is a time and firm specific demand shock capturing all factors other than firms' own price affecting demand.

Firms face competitive factor markets with the following total costs for blue collar labor, white collar labor, capital, energy and material:

$$
\begin{aligned}
& \omega_{B}\left(L_{j t}, H_{j t}\right)=w_{0 t} B_{j t}\left(1+w_{1 t} H_{j t}{ }^{\delta}\right) \\
& \omega_{W}\left(W_{j t}\right)=P_{W t} W_{j t} \\
& \omega_{K}\left(K_{j t}\right)=P_{K t} K_{j t} \\
& \omega_{E}\left(E_{j t}\right)=P_{E t} E_{j t} \\
& \omega_{M}\left(M_{j t}\right)=P_{M t} M_{j t}
\end{aligned}
$$

where $P_{W}$ is the white collar wage, $P_{K}$ is the user cost of capital, $P_{E}$ is the per unit cost of energy and $P_{M}$ is the per unit cost of materials. In the case of blue collar employees, total compensation is the product of employment $B_{j t}$ times a wage function that depends on total hours $H_{j t}$. This tries to capture the fact that the marginal wage is not constant. As the firm tries to increase hours per worker, it must resort to overtime hours and a premium must be paid at least for some workers.

\footnotetext{
${ }^{2}$ For simplicity all firms are assumed to have the same production function.
} 
This function is indexed by parameters $w_{0}$ (straight-time blue collar wage), $w_{1}$ (overtime premium) and $\delta$ (marginal wage elasticity). ${ }^{3}$

After taking logs, the first order conditions for both types of employment, hours, capital, energy and materials yield the following system of equations (where $\bar{X}$ denotes the frictionless levels, $\tilde{\bar{X}}=\ln \bar{X}$ for variables and $\widetilde{P}=\ln P$ for input prices, and subscripts are omitted to simplify notation):

$\widetilde{\bar{K}}=\frac{\frac{\eta}{\eta-1}\left(-\ln \frac{\eta-1}{\eta}-\widetilde{D}\right)+\frac{\eta}{\eta-1}\left(\widetilde{P}_{K}-\ln \alpha\right)-\beta(\widetilde{\bar{B}}+\widetilde{\bar{H}})-\mu \widetilde{\bar{W}}-\gamma \widetilde{\bar{E}}-\varphi \widetilde{\bar{M}}-\tilde{\bar{V}}}{\alpha-\frac{\eta}{\eta-1}}$

$\widetilde{\bar{B}}=\frac{\frac{\eta}{\eta-1}\left(-\ln \frac{\eta-1}{\eta}-\widetilde{D}\right)+\frac{\eta}{\eta-1}\left(\widetilde{P}_{B_{0}}-\ln \beta\right)+\frac{\eta}{\eta-1}\left(1+\widetilde{P}_{B_{l}} \bar{H}^{\delta}\right)-\alpha \widetilde{\bar{K}}-\beta \widetilde{\bar{H}}-\mu \widetilde{\bar{W}}-\gamma \widetilde{\bar{E}}-\varphi \widetilde{\bar{M}}-\tilde{\bar{V}}}{\beta-\frac{\eta}{\eta-1}}$

$\widetilde{\bar{H}}=\frac{\frac{\eta}{\eta-1}\left(-\ln \frac{\eta-1}{\eta}-\widetilde{D}\right)+\frac{\eta}{\eta-1}\left(\widetilde{P}_{B_{0}}-\ln \beta\right)+\frac{\eta}{\eta-1}\left(\widetilde{P}_{B_{1}}+\widetilde{\bar{B}}\right)+\frac{\eta}{\eta-1} \ln \delta-\alpha \tilde{\bar{K}}-\beta \tilde{\bar{L}}-\mu \widetilde{\bar{W}}-\gamma \widetilde{\bar{E}}-\varphi \tilde{\bar{M}}-\tilde{\bar{V}}}{\beta-\delta \frac{\eta}{\eta-1}}$

$\widetilde{\bar{W}}=\frac{\frac{\eta}{\eta-1}\left(-\ln \frac{\eta-1}{\eta}-\widetilde{D}\right)+\frac{\eta}{\eta-1}\left(\widetilde{P}_{W}-\ln \mu\right)-\alpha \widetilde{\bar{K}}-\beta(\widetilde{\bar{B}}+\widetilde{\bar{H}})-\gamma \widetilde{\bar{E}}-\varphi \widetilde{\bar{M}}-\widetilde{\bar{V}}}{\mu-\frac{\eta}{\eta-1}}$

$\widetilde{\bar{E}}=\frac{\frac{\eta}{\eta-1}\left(-\ln \frac{\eta-1}{\eta}-\widetilde{D}\right)+\frac{\eta}{\eta-1}\left(\widetilde{P}_{E}-l \eta \eta\right)-\alpha \tilde{\bar{K}}-\beta(\tilde{\bar{B}}+\widetilde{\bar{H}})-\mu \widetilde{\bar{W}}-\varphi \widetilde{\bar{M}}-\tilde{\bar{V}}}{\gamma-\frac{\eta}{\eta-1}}$

${ }^{3}$ As in Caballero and Engel (1993), our functional form for the blue collar compensation implies that in the absence of employment adjustment costs, the firm would always choose the same number of hours per worker, and adjust to productivity and demand shocks only varying employment. 
$\widetilde{\bar{M}}=\frac{\frac{\eta}{\eta-1}\left(-\ln \frac{\eta-1}{\eta}-\widetilde{D}\right)+\frac{\eta}{\eta-1}\left(\widetilde{P}_{M}-\ln \varphi\right)-\alpha \widetilde{\bar{K}}-\beta(\widetilde{\bar{B}}+\widetilde{\bar{H}})-\mu \widetilde{\bar{W}}-\gamma \widetilde{\bar{E}}-\widetilde{\bar{V}}}{\varphi-\frac{\eta}{\eta-1}}$

In absence of adjustment costs for hours, energy and materials, the frictionless levels of those inputs coincide with the observed levels. Therefore, the first order conditions can be reduced to a system of three equations and three unknowns. After solving it, we can write the log of the frictionless levels of capital, blue-collar employment and white collar employment as functions of the parameters of the model to be estimated and observed variables as follows:

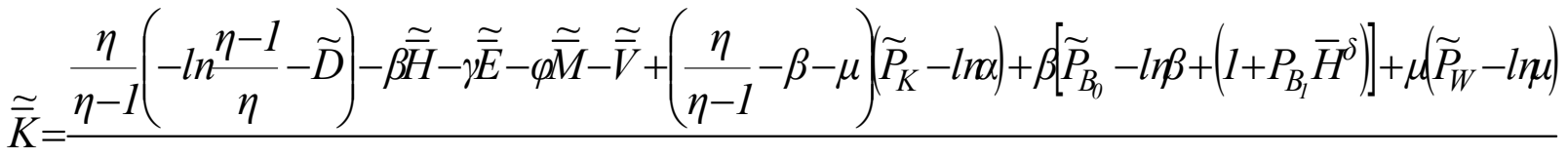

$$
\begin{aligned}
& \alpha+\beta+\mu-\frac{\eta}{\eta-1}
\end{aligned}
$$

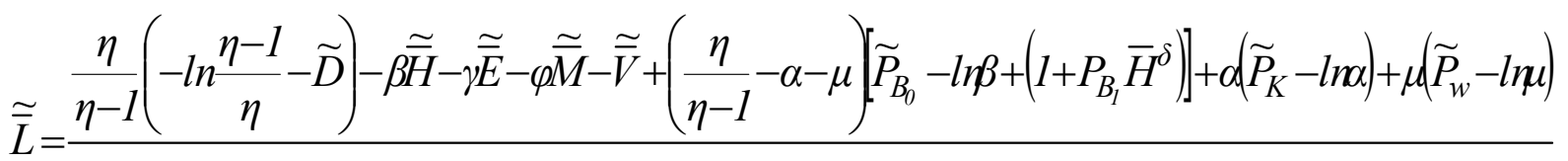

$$
\begin{aligned}
& \alpha+\beta+\mu-\frac{\eta}{\eta-1} \\
& \widetilde{\bar{W}}=\frac{\frac{\eta}{\eta-1}\left(-\ln \frac{\eta-1}{\eta}-\widetilde{D}\right)-\beta \tilde{\bar{H}}-\gamma \widetilde{\bar{E}}-\varphi \widetilde{\bar{M}}-\widetilde{\bar{V}}+\left(\frac{\eta}{\eta-1}-\alpha-\beta\right)\left(\widetilde{P_{W}}-\ln \mu\right)+\beta\left[\widetilde{P}_{B_{0}}-\ln \beta+\left(1+P_{B_{1}} \bar{H}^{\delta}\right)\right]+\alpha\left(\widetilde{P}_{K}-\ln \alpha\right)}{\alpha+\beta+\mu-\frac{\eta}{\eta-1}}
\end{aligned}
$$

\subsection{Desired factor levels and output gap}

Frictionless levels are not the same as the desired ones. Both concepts differ in that the desired levels are the ones observed if adjustment costs are momentarily removed, while frictionless levels are the ones observed in absence of adjustment costs in all periods. Bertola and Caballero (1994) state reasonable conditions under which the desired levels can be approximated, up to a constant, by frictionless levels. 


$$
\begin{aligned}
K_{j t}^{*} & =\bar{K}_{j t} \theta_{K j} \\
B_{j t}^{*} & =\bar{B}_{j t} \theta_{B j} \\
W_{j t}^{*} & =\bar{W}_{j t} \theta_{W j}
\end{aligned}
$$

where $\left(K_{j t}^{*}, \bar{K}_{j t}\right),\left(B_{j t}^{*}, \bar{B}_{j t}\right)$ and $\left(W_{j t}^{*}, \bar{W}_{j t}\right)$ are respectively the desired and frictionless levels of capital, blue-collar and white collar employment. The firm specific constants to be estimated are $\theta_{K j}, \theta_{B j}$ and $\theta_{W j}$.

Following Caballero, Engel and Haltiwanger $(1995,1997) \theta_{K j}, \theta_{B j}$ and $\theta_{W j}$ can be determined as the ratio between the actual and frictionless capital, blue collar and white collar employment, for the year where investment and employment growth for each type take their median values respectively. It is then implicitly assumed that, in the year of the median employment growth and median investment, the desired and the actual adjustment of employment and capital respectively coincide.

To define the output gap we make the extra assumption that total factor productivity is an exogenous shock not dependent on the levels of the inputs. Given the production function and the previous assumption that the desired and actual hours, materials and energy consumption coincide, the desired output is:

$$
Y_{j t}^{*}=K_{j t}^{* \alpha}\left(B_{j t}^{*} H_{j t}\right)^{\beta} W_{j t}^{* \mu} E_{j t}^{\gamma} M_{j t}^{\phi} V_{j t}
$$

Adding firms' output and desired output it is straightforward to estimate the output gap.

\subsection{Estimation of various variables and parameters}

\subsubsection{Productivity shock estimation}

We use Levinsohn and Petrin's (2003) methodology to obtain a measure of total factor productivity by estimating a production function where an electricity consumption variable is used to control for unobservables. Such method specifically controls for two problems in this type of estimations: the selection problem (i.e. in a panel a researcher would only observe the surviving firms, hence those likely to be the most productive), and the simultaneity problem (the input choices of firms conditional on the fact that they continue to be in activity depend on their productivity).

Given the production function specification in equation (6) we compute total factor productivity as: 


$$
\widetilde{V}_{j t}=\widetilde{Y}_{j t}-\hat{\alpha} \widetilde{K}_{j t}-\hat{\beta}\left(\widetilde{B}_{j t}+\widetilde{H}_{j t}\right)-\hat{\mu} W_{j t}-\hat{\gamma} E_{j t}-\hat{\phi} M_{j t}
$$

where $\hat{\alpha}, \hat{\beta}, \hat{\mu}, \hat{\gamma}$ and $\hat{\phi}$ are the estimated factor elasticities for capital, blue collar employment hours, white collar employment, electricity and materials respectively, and all variables are expressed in logs. The estimated coefficients of the production function are shown in Table 1. The null hypothesis of constant returns of scales is not rejected, though is not imposed. The standard errors are estimated across 100 bootstrapped samples.

\subsubsection{Demand shock estimation}

We also estimate establishment level demand shocks based on the inverse demand equation (7). The inverse demand function is estimated in logs, and the demand shock recovered as the residual.

$$
d_{j t}=\ln \hat{D}_{j t}=\ln P_{j t}+\hat{\varepsilon} \ln Y_{j t}
$$

where $\varepsilon=-\frac{1}{\eta}$. In order to identify the elasticity of the demand equation we estimate a two equation system of demand and supply, using three stage least squares. Supply shifters include total factor productivity and a sector wage index, while time and industry effects are also included. Results are presented in Table 2.

\subsubsection{Input prices and compensation function estimation}

Our database has input prices for goods, white collars, materials and energy. They all vary across years and four digit sectors. For the user cost of capital we use a constant value of $10 \%$. The only parameters remaining to be estimated are those of the compensation function for blue collar workers.

The postulated compensation function for blue collars is stated in (8). ${ }^{4}$ Bils (1987) and Cooper and Willis (2004) estimate for the U.S. the wage marginal elasticity $\delta$ to be 2 . Eslava et al (2005) working with Colombian firms calibrate $\delta$ to 2 and $w_{1}$ to the legally overtime premium and estimate from their data the straight-time wage $w_{0}$. We also calibrate $\delta$ to 2 and perform a non linear least squares procedure to estimate the parameters $w_{0}$, and $w_{1}$. Table 3 shows the results of this estimation.

\footnotetext{
${ }^{4}$ It would be desirable to postulate a similar function for white collar workers too, but our database does not include information on hours worked by white collars.
} 


\section{Adjustment functions and the effects of policy changes in the adjustment process}

\subsection{Estimated adjustment functions}

In this section we present our baseline adjustment function estimations. Figures 1 to 3 display the histograms of the estimated shortages. Their distributions are roughly symmetric. Table 4 presents summary statistics on the desired, frictionless and actual input levels. All correlations are high suggesting the models predicts reasonably well. For the whole manufacturing sector the level of desired white collar jobs is $15 \%$ above the actual one and the desired blue collar jobs and capital are $10 \%$ above the actual ones.

Figure 4 shows the mean and median output gap defined as the ratio between firm's desired output and actual output. The mean output gap for the whole period is $2 \%$. The gap follows the Uruguayan business cycle. In 1982, Uruguay suffered a deep exchange rate and financial crisis that led to three years of recession. In such years the desired output was below the observed one. In 1985, the economy started to recover but the desired output was still lower than the actual one. The next five years are expansion years and firms tend to desire more employment and capital than what they actually had implying positive output gaps. Due to inflationary problems the government in 1990 undertook contractionary fiscal policies that led to a halt in GDP growth that was resumed two years later. This implied the negative gaps in the early nineties and the positive ones of the last years of our sample.

Turning now to the adjustment functions themselves, we estimate the parameters in equations (5) by panel fixed effects regressions. For each factor separately we generate a dummy variable that takes the value of 1 when the shortage is positive and 0 otherwise. Interacting this dummy with the factor shortage and with the cube of the shortage we allow for asymmetric effects of shortages and surpluses, i.e. we allow for different levels as well as slopes of the adjustment for shortages and surpluses.

The adjustment functions for white and blue collar employment and capital are displayed in figure 5. Since our specification implies that every shortage in every factor and the interactions between them can potentially have an effect on the adjustment of each factor, we present our baseline estimation setting the shortages of other factors at zero. The percentage of the adjustment is plotted as a function of the shortage. Negative shortages would indicate that the past level of the input is above the desired one (factor surplus), hence to close this gap the firm needs to decrease this factor, and it finds itself in the job or capital destruction side. Conversely, positive shortages show a past level of the input below the desired one, hence if the firm wants to close the gap, it will be in the factor creation side, i.e. it will invest or hire.

Table 5 reports the estimated coefficients of the baseline adjustment functions. The significance of the Pos interactions variable shows that the adjustment function in all cases is asymmetric with respect to shortages and surpluses, with the exception of capital, where there is a difference in the slope only.

Figure 5 also shows that there is an asymmetric behavior in the adjustment process. First, for small values of the observed shortage, white and blue collar employment adjustment functions 
show an upward shift in the positive side. This means that firms tend to adjust a larger fraction of the gap between the desired and the actual employment when the observed levels are below the desired ones, i.e. firm finds it easier to create labor than to destroy it except when the destructive adjustment is large.

Since in most cases the cross product terms that include the adjusting factor are significant, we can infer that, as conjectured, shortages of other factors are relevant to understand the adjustment process. The negative sign of this cross shortages terms imply that large shortages of one factor lead to less responsiveness in adjustment in the creation side of other factors but larger adjustment in the destruction side. To observe the effect of the rest of the factors in each adjustment function, figures 6 to 8 show separately the adjustment function of each factor, where the shortages in the other factors are set at their mean values, and their mean values plus and minus one standard deviation respectively.

The lumpiness of the adjustment process is shown by the fact that the size of the adjustment is increasing in the absolute value of the shortage observed in almost all cases, both in the creation and the destruction side. Our results also confirm nonlinearity of the adjustment process, since nonlinear terms are in all tables statistically significant.

Another asymmetry is given by the fact that estimated adjustment functions display a smaller slope in the creation side than in the destruction side. The differences in the slopes can be understood together with the differences in the intercepts. The higher intercept in the creation side indicates higher adjustment for firms with small factor shortages, while a relatively flat slope of the adjustment schedule shows that they are able only to undertake smaller adjustments when there is a high positive shortage. On the contrary, the lower adjustments for small surpluses are associated with firms closing higher percentages of the gaps when surpluses become large enough in absolute values. A natural interpretation of this result is that there are larger adjustment costs associated to factor destruction (severance payments, loss of specific human capital, etc.) than to factor creation (search, training, etc.).

Comparing the different factor adjustment functions, both in the creation and the destruction side, the slopes for white collar are larger than for blue collar labor. Such features can be seen as related to the differences in adjustment costs for each factor. Labor unions tend to be stronger in industries more intensive in blue collar labor; hence this can be related to lower adjustment levels when shortages are large in the destruction side. The white collar adjustment function has higher slope than blue collar adjustment on both sides. When the shortage is small in absolute value, adjustment is lower in white collar than in blue collar. Conversely, if the shortage is large in absolute value, a larger proportion of the gap is closed for white collars than for blue collars.

Probably this relates to the fact that white collar labor includes workers with specific human capital, which is difficult to create. Therefore firms probably may be willing to accept small shortages without adjusting, but the adjustment will be fuller when the shortage becomes large in absolute value. For instance, consider a firm that has more clerks that needed, but these clerks are familiar with the workings of the firm: if this shortage is not too large, the firm may prefer to keep these extra workers. On the other hand, if blue collars have less specific training, they may 
be more easily disposed. On the creation side, hiring an extra clerk implies higher training costs; hence the firm may prefer to use the existent workers more intensively if the shortage is small. If the shortage becomes large enough, the cost of the extra hours will be higher than the training cost of the newly hired white collar workers.

Finally, the effects of the shortage of the other factors in the adjustment function are captured both by the direct effect and the cross product effects terms, but their impact comes mostly from the latter. A negative sign of the coefficients of the cross product of the shortages (see Table 5) causes that the higher the shortages of the other factors, the higher the adjustment in the destruction side, and the lower the adjustment in the creation side (see figures 6 to 8). Many firms downsized and even exited over the period of trade liberalization. This implied the simultaneous destruction of labor (both white and blue collar) and capital. This explains why higher shortages in absolute value for capital (white collar employment) provoke higher adjustment on white collar (capital). According to the evidence presented in Casacuberta, Fachola and Gandelman (2004), firms in order to remain competitive switched towards more capital intensive production methods. Therefore, the lower the shortage in capital (employment), the higher the adjustment in employment (capital).

\subsection{Trade reform effects in the adjustment process of firms}

Vaillant (2000) describes the trade liberalization process in Uruguay, finding that trade policy in the nineties sought to continue and deepen the openness process started in the seventies, intended to end the anti-export bias that characterized previous import substitution policies. With the recovery of democratic institutions in 1985, political pressure for the modification of trade policy grew, but the government did not modify the main policies, and there was only a slightly higher protection as a result of the use of non-tariff barriers. In 1990, a program of scheduled tariff reductions began, and the signature of the Mercosur treaty led to the establishment of an imperfect customs union with its neighboring countries.

To study the impact of trade liberalization and international exposure on the adjustment process we estimate several adjustment functions. We are looking at the way sectoral shocks (protection level, trade liberalization) affect the way firms respond to idiosyncratic shortages. Industries that were more open from the beginning should experience lower shifts in their adjustment functions due to the generalized higher international exposure.

A problem with using tariffs or change in tariffs in the right hand side of equations is that they may possibly be endogenous. In our case this problem is less severe due to the fact that Uruguay is a relatively minor player integrated with its larger neighbor economies in Mercosur. Hence the common external tariff and the changes in Uruguayan tariffs to converge to the trade block protection level are basically affected by Argentinean and Brazilian political players and beyond control for local firms. ${ }^{5}$

Descriptive statistics of our policy and firm variables are presented in Table 6 . We find that the average tariff was reduced significantly from an average of 43\% to 14\% between 1985 and 1995 . On average, annual tariff changes accelerated from $-2.1 \%$ before 1990 to $-3.0 \%$ after 1990 .

\footnotetext{
${ }^{5}$ This is discussed in more detail in Casacuberta, Fachola and Gandelman (2004)
} 
The average ratio of exports over sales did not change drastically over the years. The start of the 1990 decade is associated not only with trade openness, but also with a significant appreciation

of the peso, linked to an exchange rate based anti-inflation policy, which caused a deterioration of relative prices that affected exporting firms. Towards the end of our sample period (1995) only a slight recovery of the ratio of exports to total sales is observed.

\subsection{Before and after 1990}

The simplest experiment is to break the panel in two periods, 1982-1989 and 1990-1995, and estimate the adjustment functions in each one of them. In the second period was when most of the import tariff reductions took place and the Mercosur was established.

To analyze the pre and post Mercosur shifts in the adjustment functions, we interact the intercept and each factor's own shortage terms (allowing for asymmetric effects in the creation and destruction sides) in the adjustment equations with a time dummy that takes the value 1 for observations in 1990-1995 and 0 elsewhere. Table 7 displays the estimated pre and post 1990 adjustment functions. In turn, figures 9,10 and 11 show respectively the pre and post adjustment function estimations for each of the three factors we are analyzing.

The results lead to conclude that there was effectively a shift in the adjustment functions between both periods. A clear pattern emerges in the creation side for the three factors of production: the level increases while the slope remains roughly constant. This implies that firms adjust a higher fraction of their shortages suggesting lower adjustment costs at least for the creation side.

The blue collar adjustment pattern differs before and after 1990. While for the whole period adjustment functions (figure 5) the intercept is higher in the creation side, the pre Mercosur function (figure 10) shows the opposite: a larger fraction of the gap is closed in the destruction side than in the creation side. The post Mercosur function shows a much higher fraction of the gap closed when shortages are positive. Though there is a very small fraction of adjustment when surpluses are small in absolute value, the negative side of the adjustment function becomes steeper after Mercosur.

For white collar labor, there is basically no effect on the destruction side. In the case of capital the adjustment function becomes flatter in the destruction side, pointing towards lower lumpiness.

\subsection{Changes in import taxes}

We also estimate adjustment functions to study the effect of changes in tariffs with our shortage terms. Again a policy variable is interacted with each factor's own shortage effect on the adjustment functions. Table 8 displays the estimated coefficients. In all regressions at least one policy interaction is significant. Figures 12, 13 and 14 show the estimated functions for tariff reductions of 0,2 and 4 percentage points. 
While for capital the impact of tariff reductions is really minor, a pattern emerges for both types of labor, in which the fraction of the gap actually adjusted decreases in the creation side, while increases in the destruction side. Firms in sectors that experienced higher tariff reductions and had to destroy employment adjusted a larger proportion than those not so exposed. On the creation side it was the opposite: firms with lower tariff reductions adjusted a larger proportion of their shortages.

\subsection{Tariff trade barrier levels}

This exercise is similar to the previous experiment, but instead of using the import tax change in the firm's sector as a shifter of the adjustment functions, we use the import tax level. Table 9 shows the regression coefficients. Most policy interaction terms are statistically significant for blue collar and capital. For white collar only the constant shifter for the creation side changes significantly. Figures 15, 16 and 17 display the estimated functions for tariff levels of 10, 20 and 30 percent points.

Lower tariff levels are associated to higher adjustment on the creation side, especially for blue collar jobs but also for white collar jobs and capital. The destruction side seems not to change with tariff levels in the case of white collar adjustment functions. For capital and blue collar labor, higher tariff levels are associated with lower adjustments in the destruction side, the opposite than the creation side.

This is an indirect way of showing that protection may in fact destroy jobs, rather than create. If shocks to firm are iid, our result implies that protection will lead to lower levels of employment. The reason may have to do with firms' expectations. For instance suppose there is a generalized positive demand shock. A firm in a highly protected sector will not adjust completely in the presence of adjustment costs (e.g., firing workers) unless the government has credibly committed to maintain protection. If there is any risk that the tariff will go down, then the firm may be more reluctant to hire many workers than a similar firm in other sector that is not exposed to the risk of the government reducing tariffs. The same applies on the job destruction side. A highly protected firm that suffers a negative shock will be more likely to fire workers if the government's tariff is not a credible permanent policy.

\subsection{Export market orientation}

Uruguay's industrial structure was in the mid eighties basically composed by a reduced number of traditional products exporting firms and by sectors developed under the imports substitution process. We estimate how the adjustment functions of the firm are affected if they are more export or domestic market oriented, as measured by the percentage share of export sales in the firm's total sales.

To do so we interact the percentage of exports over sales variable with each factor's own shortage on the adjustment functions. Table 10 shows the estimated coefficients, while figures 18,19 and 20 show the shifts in the estimated functions for export shares of $0 \%, 25 \%$ and $50 \%$. 
In those more export oriented firms the percentage of adjustment is larger both in the creation and destruction sides for blue collar labor, implying lower adjustment costs. Firms more export oriented, when their desired blue collar employment level is below the actual one, they adjust a higher share of the gap than firms oriented to the domestic market. The causality may go in the opposite direction. In order to be able to export, firms need to be more efficient, and therefore need to have more ability to adjust factor inputs.

There does not seem to be a clear significant pattern between export oriented and domestic market oriented firms with respect to capital and white collar adjustment functions.

\section{Conclusions}

This paper intends to use micro data to improve our understanding of the effects of policy measures on the adjustment of factors of production. On the one hand, the paper finds evidence supporting a number of regularities that the previous literature on adjustment functions has highlighted.

Our investigation confirms that aggregate investment and job creation might be seen as the result of lumpy and discontinuous microeconomic decisions. Individual adjustment constraints depart significantly from the constraints implicit in the quadratic adjustment cost model. There are several sources of irreversibilities (technological, market-induced, increasing returns in the adjustment technology). The evidence provided seems to confirm a pattern that has important nonlinear features, hence consistent with such constraints. This impacts the use of all factors of production, particularly employment.

The existence of adjustment costs implies that the desired levels of white and blue collar employment and capital often deviate from the observed ones. In our data these deviations imply that the yearly gaps might be above $10 \%$. To have an idea of the importance of the adjustment costs, it is useful to consider that for the whole period the average output gap is of $2 \%$.

On the other hand, the paper intended to assess the effects of protection and trade liberalization on firms' adjustment process. The constraints arising from the adjustment cost functions may become an important part of the policy analysis. Our results point to a significant shift in the adjustment functions for all the production factors before and after 1990, corresponding with significant changes in the trade openness process. The shifts point towards larger fractions of the gaps closed in the creation side, and lower in the destruction side.

Trade policy as measured by tariffs levels and their reductions also proved to significantly shift the adjustment functions. Firms in less protected sectors have shown higher adjustment fractions in the creation side and lower in the destruction side, particularly for blue collar labor. Sectors facing larger tariff changes, adjust less in the creation side, particularly for blue collars, and more on the destruction side. In the context of tariff reductions of Mercosur, those sectors more highly protected were probably those that faced the largest tariff reductions. 


\section{References}

Black S. and L. Lynch (1997) How to compete: the impact of workplace practices and information technology on productivity, NBER WP 6120.

Bils, M., (1987) The cyclical behavior of marginal cost and price, The American Economic Review, Vol 77 No. 5.

Caballero, R., and E. Engel (1993) Microeconomic adjustment hazard and aggregate dynamics, Quarterly Journal of Economics 108 (2) : 359-383.

Caballero, R., E. Engel and J. Haltiwanger (1995) Plant-Level Adjustment and Aggregate Investment Dynamics, Brookings Papers on Economic Activity 2: 1-54.

Caballero, R., E. Engel and J. Haltiwanger (1997) Aggregate employment dynamics: building from microeconomic evidence, American Economic Review 87 (1): 115-137.

Cassoni, A, G. Fachola and G. Labadie (2001) The Economic Effects of Unions in Latin America: Their Impact on Wages and the Economic Performance of Firms in Uruguay, Research Department WP R466, Inter American Development Bank.

Casacuberta, C., G. Fachola, and N. Gandelman, (2004) The Impact of Trade Liberalization on Employment, Capital and Productivity Dynamics: Evidence from the Uruguayan Manufacturing Sector, Journal of Policy Reform, Vol 7 (4)

Cooper, R., and J. Willis, (2004) The economics of Labor adjustment: mind the gap, The American Economic Review, Vol 94 No. 4

Eslava, M., J. Haltiwanger, and M. Kugler, (2005) Heterogeneous adjustments of employment and capital after factor market deregulation. Mimeo.

Davis, S., and J. Haltiwanger, (1992) Gross job creation gross job destruction and employment reallocation, Quarterly Journal of Economics, 107(3)

Davis, S., J. Haltiwanger, and S. Schuh, (1996) Job creation and destruction, MA: MIT Press

Levinsohn, J., and A. Petrin, (2003) Estimating production functions using inputs to control for unobservables, Review of economic studies, Vol 70 (2).

Levinsohn, J., A. Petrin, and B. Poi (2003) Production function estimation in Stata using inputs to control for unobservables, Stata Journal, 4 (2).

Vaillant, M., (2000) Limits to trade liberalization: a political economy approach, Ph.D. dissertation, Universiteit Antwerpen UFSIA. 


\section{Appendix: Data}

In this paper we exploit Uruguayan establishment level data covering a considerably long period of time. We use annual establishment level observations from the Manufacturing Survey conducted by the Instituto Nacional de Estadística (INE) for the period 1982-1995. The surveysampling frame encompasses all Uruguayan manufacturing establishments with five or more employees.

The INE divided each four digit International Standard Industrial Classification (ISIC) sector in two groups. All establishments with more than 100 employees were included in the survey; the random sampling process of firms with less than 100 employees satisfies the criterion that the total employment of all the selected establishments must account at least for $60 \%$ of the total employment of the sector according to the economic Census (1978 or 1988).

The data for the whole period are actually obtained from two sub sample sets: from 1982 until 1988 and from 1988 until 1995. In 1988 the Second National Economic Census was conducted. After that, the INE made a major methodological revision to the manufacturing survey and changed the sample of establishments. The statistical analysis was also performed controlling for the sample of origin. Firms entering the sample in 1988 behave similarly than firms from the old sample. Differences in behavior in white collar and capital adjustment are small. For the firms in the new sample the slope of the blue collar adjustment function is higher in the creation side while lower in the destruction side. It is hard to evaluate differences by sample in the sign or size of the policy impacts.

In total, we have 627 different establishments present in at least one period. There are 208 starting in 1982, of which just 185 make it to 1995. The 1988 sample, is composed of 304 establishments included for the first time in that year, and 254 from the old sample not all of which are to be followed in subsequent years.

\subsection{Capital}

To construct the establishment capital stock series, we follow a methodology close to Black and Lynch (1997). The 1988 Census reports information on the capital stock. We use machinery capital. We avoid overestimation of the amount of depreciation by calculating an average depreciation rate by industrial sector and year. The resulting depreciation rate is then used for all firms within each sector yearly. We further exclude the value of assets sold in our measure of capital, assuming assets have been totally depreciated at that point. Thus, the equation for estimating the capital stock for years later than 1988 is:

$$
K_{j i t}=K_{j i t-1}+I_{j i t}-\delta_{i t} K_{j i t-1}
$$

with 


$$
\delta_{i t}^{x}=\frac{\sum_{j} D_{j i t}}{\sum_{j} K_{j i t}}
$$

where $j$ indexes firms; $i$ the industrial sector, $t$ the year. $K$ is the capital stock; $I$ is amount invested; $\delta$ is the depreciation rate; and $D$ is depreciation in pesos.

For years before 1988, the equation is reversed and each year's capital is obtained by subtracting each year's investment and applying a depreciation factor. The depreciation rate before 1988 was not available and was estimated using 1988 data. We ran a simple OLS model for the log of total depreciation conditional on the log of gross output, capital stock, total hours and electricity usage. Using this model we predicted the before 1988 depreciation levels.

$$
K_{j i t-1}=\left(K_{j i t}-I_{j i t}\right) \cdot\left(\frac{1}{1-\hat{\delta}_{j i t}}\right)
$$

\subsection{Tariffs}

We use data on import tariffs for the period 1985-1995 from Vaillant (2000) and Casacuberta, Fachola and Gandelman (2004). 


\section{Tables}

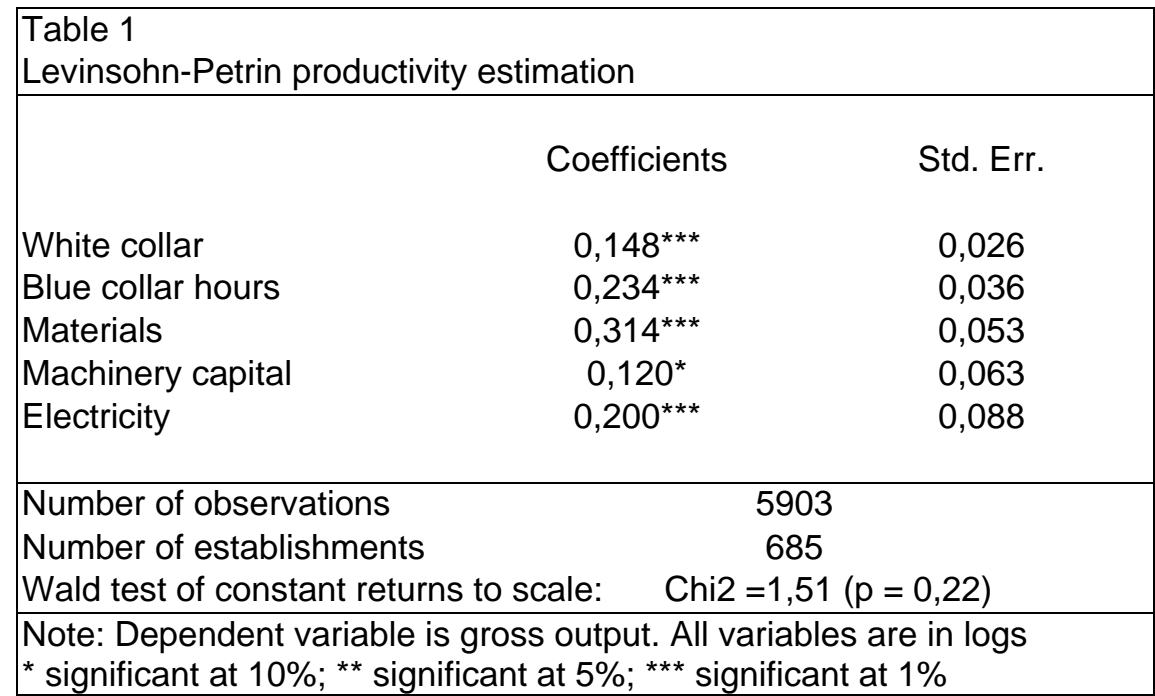

\begin{tabular}{|c|c|c|}
\hline \multicolumn{3}{|c|}{$\begin{array}{l}\text { Table } 2 \\
\text { Demand shock estimation } \\
\text { Three-stage least squares regression }\end{array}$} \\
\hline & Obs & Parameters \\
\hline Demand equation & 5903 & 9 \\
\hline \multirow[t]{2}{*}{ Supply equation } & 5903 & 16 \\
\hline & \multicolumn{2}{|c|}{ Demand equation } \\
\hline Price & $-1,156^{*}$ & 0,619 \\
\hline \multicolumn{3}{|l|}{ Supply equation } \\
\hline Price & $0,863^{*}$ & 0,520 \\
\hline Total factor productivity & $0,006^{*}$ & 0,003 \\
\hline Wage Index & $-0,376^{\star *}$ & 0,166 \\
\hline \multicolumn{3}{|c|}{$\begin{array}{l}\text { Note: Dependent variable is gross output. } \\
\text { Endogenous variables: gross output and price. } \\
\text { Exogenous variables not reported: year dummies (supply) and } 3 \\
\text { digit ISIC industry dummies (demand) } \\
{ }^{*} \text { significant at } 10 \% \text {; ** significant at } 5 \% \text {; *** significant at } 1 \%\end{array}$} \\
\hline
\end{tabular}




\begin{tabular}{|c|c|c|}
\hline $\begin{array}{l}\text { Table } 3 \\
\text { Compensation }\end{array}$ & ion estimation & \\
\hline & Coefficient & Std. Err. \\
\hline$w_{0}$ & $0,816^{\star \star *}$ & 0,016 \\
\hline $\mathrm{w}_{1}$ & $1,24 \mathrm{E}-07^{* * *}$ & 6,36E-09 \\
\hline Delta & 2 & \\
\hline Number of obs & 6198 & \\
\hline R-squared & 0.832 & \\
\hline Adj R-squared & 0.844 & \\
\hline
\end{tabular}

Table 4

Summary statistics: actual, desired and frictionless factor levels

Mean values

Variable

DW

Observations

Mean

5512

5512

37

Std. Dev.

W

5512

32

75

DB

5512

115

63

B

5512

105

208

DK

5512

275333

168

K

249379

788947

657317

Pariwise Correlations:

$\begin{array}{cccc} & \text { FW } & \text { DW } & \text { W } \\ \text { FW } & 1.00 & & \\ \text { DW } & 0.75 & 1.00 & 1.00 \\ \text { W } & 0.72 & 0.85 & \\ & \text { FB } & \text { DB } & \\ \text { FB } & 1.00 & & \\ \text { DB } & 0.66 & 1.00 & 1.00 \\ \text { B } & 0.65 & 0.88 & \\ & & & \\ \text { FK } & 1.00 & \text { DK } & \\ \text { DK } & 0.66 & 1.00 & 1.00 \\ \text { K } & 0.63 & 0.82 & \end{array}$

Note: $\mathrm{K}=$ actual capital, $\mathrm{FK}=$ frictionless capital, $\mathrm{DK}=$ desired capital Idem with $\mathrm{B}, \mathrm{FB}, \mathrm{DB}$ and $\mathrm{W}, \mathrm{FW}, \mathrm{DK}$ for blue and white collar 


\begin{tabular}{|c|c|c|c|}
\hline \multicolumn{4}{|c|}{$\begin{array}{l}\text { Table } 5 \\
\text { Estimated parametric adjustment functions } \\
\text { Baseline specification }\end{array}$} \\
\hline & $\begin{array}{l}\text { White collar } \\
\text { adjustment }\end{array}$ & $\begin{array}{l}\text { Blue collar } \\
\text { adjustment }\end{array}$ & $\begin{array}{c}\text { Capital } \\
\text { adjustment }\end{array}$ \\
\hline \multirow[t]{2}{*}{ Constant } & 0.074 & 0.166 & 0.060 \\
\hline & {$[0.022]^{\star \star \star}$} & {$[0.023]^{\star \star \star}$} & {$[0.021]^{\star \star \star}$} \\
\hline \multirow[t]{2}{*}{ Pos Shortage } & 0.137 & 0.1406 & 0.026 \\
\hline & {$[0.039]^{\star \star \star}$} & {$[0.037]^{\star \star \star}$} & {$[0.036]$} \\
\hline \multirow[t]{2}{*}{$(\text { ShortageW })^{\wedge} 2$} & 0.189 & 0.029 & 0.006 \\
\hline & {$[0.011]^{\star \star *}$} & {$[0.012]^{\star \star}$} & {$[0.013]$} \\
\hline \multirow[t]{2}{*}{$(\text { ShortageW })^{\wedge} 2^{\star}$ Pos } & -0.103 & & \\
\hline & {$[0.017]^{\star \star \star}$} & & \\
\hline \multirow[t]{2}{*}{$(\text { ShortageB })^{\wedge} 2$} & -0.009 & 0.099 & -0.025 \\
\hline & [0.015] & {$[0.012]^{\star \star \star}$} & {$[0.013]^{\star}$} \\
\hline \multirow[t]{2}{*}{$(\text { ShortageB })^{\wedge} 2^{\star}$ Pos } & & -0.071 & \\
\hline & & {$[0.019]^{\star \star *}$} & \\
\hline \multirow[t]{2}{*}{$(\text { ShortageK })^{\wedge} 2$} & -0.012 & 0.021 & 0.179 \\
\hline & [0.011] & {$[0.010]^{\star \star}$} & {$[0.007]^{\star \star *}$} \\
\hline \multirow[t]{2}{*}{$(\text { ShortageK })^{\wedge} 2^{*}$ Pos } & & & -0.137 \\
\hline & & & {$[0.013]^{\star \star \star}$} \\
\hline \multirow[t]{2}{*}{$(\text { ShortageW })^{\star}($ ShortageB $)$} & -0.042 & 0.0011 & 0.011 \\
\hline & {$[0.014]^{\star \star \star}$} & [0.013] & [0.016] \\
\hline \multirow[t]{2}{*}{$(\text { ShortageW })^{\star}($ ShortageK $)$} & -0.025 & 0.001 & -0.001 \\
\hline & {$[0.012]^{\star \star}$} & {$[0.014]$} & {$[0.012]$} \\
\hline \multirow{2}{*}{$(\text { ShortageB })^{\star}($ ShortageK $)$} & 0.026 & -0.058 & -0.059 \\
\hline & {$[0.016]$} & {$[0.0121]^{\star \star \star}$} & {$[0.011]^{\star \star \star}$} \\
\hline Observations & 4945 & 4945 & 4945 \\
\hline Number of id & 627 & 627 & 627 \\
\hline R-squared & 0.3 & 0.29 & 0.37 \\
\hline \multicolumn{4}{|c|}{$\begin{array}{l}\text { Note: Pos Shortage: Dummy }=1 \text { if Shortage is positive } \\
\text { ShortageW. ShortageB. ShortageK are the shortages for white collar. blue } \\
\text { collar and capital. Standard errors in brackets } \\
{ }^{*} \text { significant at } 10 \% \text {; ** significant at } 5 \% \text {; ** significant at } 1 \%\end{array}$} \\
\hline
\end{tabular}




\begin{tabular}{|c|c|c|c|}
\hline \multicolumn{4}{|c|}{$\begin{array}{l}\text { Table } 6 \\
\text { Policy and firm variables } \\
\text { Descriptive statistics }\end{array}$} \\
\hline & tariff (\%) & $\begin{array}{c}\text { Tariff } \\
\text { change }\end{array}$ & Export/sales \\
\hline 1982 & . & . & 0.17 \\
\hline 1983 & . & . & 0.20 \\
\hline 1984 & . & . & 0.20 \\
\hline 1985 & 42.53 & . & 0.19 \\
\hline 1986 & 38.96 & -3.47 & 0.19 \\
\hline 1987 & 35.49 & -3.46 & 0.19 \\
\hline 1988 & 32.64 & -3.46 & 0.14 \\
\hline 1989 & 32.07 & -0.57 & 0.16 \\
\hline 1990 & 31.50 & -0.57 & 0.16 \\
\hline 1991 & 24.59 & -6.97 & 0.15 \\
\hline 1992 & 20.68 & -3.91 & 0.15 \\
\hline 1993 & 17.09 & -3.54 & 0.15 \\
\hline 1994 & 17.11 & 0.02 & 0.15 \\
\hline 1995 & 14.01 & -3.14 & 0.16 \\
\hline \multicolumn{4}{|l|}{ All period } \\
\hline Mean & 26.3 & -2.8 & 0.2 \\
\hline standard dev & 9.9 & 2.7 & 0.3 \\
\hline Percentile 50 & 24.9 & -2.9 & 0.0 \\
\hline Percentile 90 & 40.0 & 0.1 & 0.8 \\
\hline \multicolumn{4}{|l|}{ Before 1990} \\
\hline Mean & 34.7 & -2.1 & 0.2 \\
\hline standard dev & 8.2 & 1.8 & 0.3 \\
\hline Percentile 50 & 34.6 & -2.2 & 0.0 \\
\hline Percentile 90 & 44.5 & 0.3 & 0.8 \\
\hline \multicolumn{4}{|l|}{1990 and after } \\
\hline Mean & 21.3 & -3.0 & 0.2 \\
\hline standard dev & 6.9 & 2.9 & 0.3 \\
\hline Percentile 50 & 19.8 & -3.1 & 0.0 \\
\hline Percentile 90 & 31.4 & 0.0 & 0.7 \\
\hline
\end{tabular}


Table 7

Estimated parametric adjustment functions Pre and post Mercosur estimation

\begin{tabular}{|c|c|c|c|}
\hline & $\begin{array}{l}\text { White collar } \\
\text { adjustment }\end{array}$ & $\begin{array}{l}\text { Blue collar } \\
\text { adjustment }\end{array}$ & $\begin{array}{c}\text { Capital } \\
\text { adjustment }\end{array}$ \\
\hline \multirow[t]{2}{*}{ Constant } & 0.089 & 0.367 & 0.071 \\
\hline & {$[0.027]^{\star \star \star}$} & {$[0.029]^{\star \star *}$} & {$[0.026]^{\star * *}$} \\
\hline \multirow[t]{2}{*}{ Pos Shortage } & 0.083 & -0.180 & -0.055 \\
\hline & {$[0.048]^{*}$} & {$[0.044]^{\star \star \star}$} & [0.042] \\
\hline \multirow[t]{2}{*}{$(\text { ShortageW })^{\wedge} 2$} & 0.174 & 0.022 & 0.008 \\
\hline & {$[0.014]^{\star \star \star}$} & {$[0.012]^{\star}$} & [0.012] \\
\hline \multirow[t]{2}{*}{$(\text { ShortageW })^{\wedge} 2 *$ Pos } & -0.107 & & \\
\hline & {$[0.024]^{\star \star \star}$} & & \\
\hline \multirow[t]{2}{*}{$(\text { ShortageB })^{\wedge} 2$} & -0.005 & 0.029 & -0.020 \\
\hline & {$[0.014]$} & {$[0.017]^{\star}$} & [0.013] \\
\hline \multirow[t]{2}{*}{$(\text { ShortageB })^{\wedge} 2^{\star}$ Pos } & & 0.012 & \\
\hline & & [0.023] & \\
\hline \multirow[t]{2}{*}{$(\text { ShortageK })^{\wedge} 2$} & -0.010 & 0.021 & 0.191 \\
\hline & {$[0.011]$} & {$[0.010]^{\star *}$} & {$[0.009]^{\star \star \star}$} \\
\hline \multirow[t]{2}{*}{$(\text { ShortageK })^{\wedge} 2^{*}$ Pos } & & & -0.148 \\
\hline & & & {$[0.017]^{\star * *}$} \\
\hline \multirow{2}{*}{$(\text { ShortageW })^{\star}($ ShortageB $)$} & -0.038 & -0.001 & 0.003 \\
\hline & {$[0.014]^{\star \star \star}$} & [0.013] & [0.016] \\
\hline \multirow[t]{2}{*}{$(\text { ShortageW })^{\star}($ ShortageK $)$} & -0.027 & -0.008 & -0.009 \\
\hline & {$[0.012]^{\star \star}$} & [0.014] & {$[0.012]$} \\
\hline \multirow[t]{2}{*}{$($ ShortageB $) \star($ ShortageK $)$} & 0.025 & -0.058 & -0.048 \\
\hline & {$[0.016]$} & {$[0.012]^{\star * *}$} & {$[0.011]^{\star * *}$} \\
\hline \multirow[t]{2}{*}{ Constant*Mercosur } & -0.035 & -0.307 & 0.022 \\
\hline & [0.032] & {$[0.031]^{\star \star \star}$} & {$[0.03]$} \\
\hline \multirow[t]{2}{*}{ Pos Shortage ${ }^{*}$ Mercosur } & 0.099 & 0.487 & 0.081 \\
\hline & {$[0.048]^{\star *}$} & {$[0.043]^{\star \star *}$} & {$[0.042]^{\star}$} \\
\hline \multirow[t]{2}{*}{$(\text { ShortageW })^{\wedge} 2^{*}$ Mercosur } & 0.025 & & \\
\hline & {$[0.018]$} & & \\
\hline \multirow[t]{2}{*}{$(\text { ShortageW })^{\wedge} 2^{\star}$ Pos $^{\star}$ Mercosur } & -0.002 & & \\
\hline & [0.028] & & \\
\hline \multirow[t]{2}{*}{$(\text { ShortageB })^{\wedge} 2^{\star}$ Mercosur } & & 0.107 & \\
\hline & & {$[0.020]^{\star \star *}$} & \\
\hline \multirow[t]{2}{*}{$(\text { ShortageB })^{\wedge} 2^{*}$ Pos $^{\star}$ Mercosur } & & -0.090 & \\
\hline & & {$[0.029]^{\star \star \star}$} & \\
\hline \multirow[t]{2}{*}{$(\text { ShortageK })^{\wedge} 2^{\star}$ Mercosur } & & & -0.062 \\
\hline & & & {$[0.014]^{\star \star \star}$} \\
\hline \multirow[t]{2}{*}{$(\text { ShortageK })^{\wedge} 2^{*}$ Pos $^{\star}$ Mercosur } & & & 0.060 \\
\hline & & & {$[0.021]^{\star \star *}$} \\
\hline Observations & 4945 & 4945 & 4945 \\
\hline Number of id & 627 & 627 & 627 \\
\hline R-squared & 0.31 & 0.33 & 0.38 \\
\hline $\begin{array}{l}\text { Note: Pos Shortage: Dumr } \\
\text { ShortageK are the shortages } \\
\text { dummy that takes the value } 1 \\
{ }^{\star} \text { significant at } 10 \% ;{ }^{* \star} \text { signific }\end{array}$ & $\begin{array}{l}\text { ge is } \\
\text { blue } \\
\text { ons afte }\end{array}$ & $\begin{array}{l}\text { itive. Shortag } \\
\text { ar and capital } \\
\text { 89. Standard }\end{array}$ & $\begin{array}{l}\text { N. ShortageB. } \\
\text { Mercosur is a } \\
\text { rors in brackets }\end{array}$ \\
\hline
\end{tabular}




\begin{tabular}{|c|c|c|c|}
\hline \multicolumn{4}{|c|}{$\begin{array}{l}\text { Table } 8 \\
\text { Estimated parametric adjustment functions } \\
\text { Tariff changes effect estimation }\end{array}$} \\
\hline & $\begin{array}{l}\text { White collar } \\
\text { adjustment }\end{array}$ & $\begin{array}{l}\text { Blue collar } \\
\text { adjustment }\end{array}$ & $\begin{array}{c}\text { Capital } \\
\text { adjustment }\end{array}$ \\
\hline \multirow[t]{2}{*}{ Constant } & 0.026 & 0.167 & 0.062 \\
\hline & [0.030] & {$[0.030]^{\star \star \star}$} & {$[0.031]^{\star \star}$} \\
\hline \multirow[t]{2}{*}{ Pos Shortage } & 0.196 & 0.116 & 0.038 \\
\hline & {$[0.050]^{\star \star \star}$} & {$[0.047]^{\star \star}$} & [0.048] \\
\hline \multirow{2}{*}{$(\text { ShortageW })^{\wedge} 2$} & 0.201 & 0.032 & 0.006 \\
\hline & {$[0.015]^{\star \star \star}$} & {$[0.013]^{\star \star}$} & [0.014] \\
\hline \multirow[t]{2}{*}{$(\text { ShortageW })^{\wedge} 2^{\star}$ Pos } & -0.076 & & \\
\hline & {$[0.023]^{\star \star \star}$} & & \\
\hline \multirow[t]{2}{*}{$(\text { ShortageB })^{\wedge} 2$} & -0.006 & 0.044 & -0.022 \\
\hline & [0.015] & {$[0.018]^{\star \star}$} & [0.016] \\
\hline \multirow[t]{2}{*}{$(\text { ShortageB })^{\wedge} 2^{*}$ Pos } & & 0.026 & \\
\hline & & {$[0.026]$} & \\
\hline \multirow[t]{2}{*}{$(\text { ShortageK })^{\wedge} 2$} & -0.009 & 0.033 & 0.179 \\
\hline & [0.013] & {$[0.012]^{\star \star \star}$} & {$[0.013]^{\star \star \star}$} \\
\hline \multirow[t]{2}{*}{$(\text { ShortageK })^{\wedge} 2^{*}$ Pos } & & & -0.119 \\
\hline & & & {$[0.020]^{\star \star \star}$} \\
\hline \multirow[t]{2}{*}{$(\text { ShortageW })^{\star}($ ShortageB $)$} & -0.047 & -0.002 & -0.013 \\
\hline & {$[0.015]^{\star \star \star}$} & [0.013] & [0.018] \\
\hline \multirow[t]{2}{*}{$(\text { ShortageW })^{\star}($ ShortageK $)$} & -0.025 & -0.013 & 0.016 \\
\hline & {$[0.014]^{*}$} & [0.015] & [0.014] \\
\hline \multirow[t]{2}{*}{$(\text { ShortageB })^{\star}($ ShortageK $)$} & 0.036 & -0.040 & -0.063 \\
\hline & {$[0.018]^{\star \star}$} & {$[0.014]^{\star \star \star}$} & {$[0.013]^{\star \star \star}$} \\
\hline \multirow[t]{2}{*}{ Constant ${ }^{\star}$ Open } & -0.019 & -0.002 & -0.017 \\
\hline & {$[0.007]^{\star \star \star}$} & {$[0.006]$} & {$[0.007]^{\star \star}$} \\
\hline \multirow[t]{2}{*}{ Pos Shortage ${ }^{\star}$ Open } & 0.012 & -0.007 & 0.020 \\
\hline & [0.009] & [0.009] & {$[0.009]^{\star \star}$} \\
\hline \multirow[t]{2}{*}{$(\text { ShortageW })^{\wedge} 2^{*}$ Open } & 0.005 & & \\
\hline & [0.004] & & \\
\hline \multirow[t]{2}{*}{$(\text { ShortageW })^{\wedge} 2^{\star} \mathrm{Pos}^{\star}$ Open } & 0.006 & & \\
\hline & [0.005] & & \\
\hline \multirow[t]{2}{*}{$(\text { ShortageB })^{\wedge} 2^{*}$ Open } & & -0.015 & \\
\hline & & {$[0.003]^{\star \star \star}$} & \\
\hline \multirow[t]{2}{*}{$(\text { ShortageB })^{\wedge} 2^{\star}$ Pos $^{\star}$ Open } & & 0.027 & \\
\hline & & {$[0.006]^{\star \star \star}$} & \\
\hline \multirow[t]{2}{*}{$(\text { ShortageK })^{\wedge} 2 *$ Open } & & & 0.008 \\
\hline & & & {$[0.004]^{\star *}$} \\
\hline$(\text { ShortageK })^{\wedge} 2^{\star} \operatorname{Pos}^{\star}$ Open & & & $\begin{array}{r}-0.008 \\
{[0.005]}\end{array}$ \\
\hline Observations & 4278 & 4278 & 4278 \\
\hline Number of id & 627 & 627 & 627 \\
\hline R-squared & 0.33 & 0.31 & 0.31 \\
\hline $\begin{array}{l}\text { Note: Pos Shortage: Dun } \\
\text { ShortageK are the shortag } \\
\text { annual change in tariff leve } \\
{ }^{*} \text { significant at } 10 \% \text {; }{ }^{*} \text { sign }\end{array}$ & $\begin{array}{l}\text { Shortage is } \\
\text { ite collar. blue } \\
\text { rd errors in bra } \\
\% ;{ }^{* \star *} \text { significa }\end{array}$ & $\begin{array}{l}\text { sitive. Short } \\
\text { collar and ca } \\
\text { kets } \\
\text { at } 1 \%\end{array}$ & $\begin{array}{l}\text { W. ShortageB. } \\
\text { l. Open is the }\end{array}$ \\
\hline
\end{tabular}




\begin{tabular}{|c|c|c|c|}
\hline $\begin{array}{l}\text { Table } 9 \\
\text { Estimated parametric adjus } \\
\text { Tariff level effect estimation }\end{array}$ & functions & & \\
\hline & $\begin{array}{l}\text { White collar } \\
\text { adjustment }\end{array}$ & $\begin{array}{l}\text { Blue collar } \\
\text { adjustment }\end{array}$ & $\begin{array}{c}\text { Capital } \\
\text { adjustment }\end{array}$ \\
\hline Constant & 0.052 & -0.181 & 0.057 \\
\hline & {$[0.051]$} & {$[0.047]^{\star \star \star}$} & [0.051] \\
\hline Pos Shortage & 0.289 & 0.778 & 0.192 \\
\hline & {$[0.080]^{\star \star \star}$} & {$[0.071]^{\star \star \star}$} & {$[0.074]^{\star \star \star}$} \\
\hline$(\text { ShortageW })^{\wedge} 2$ & 0.207 & 0.022 & 0.009 \\
\hline & {$[0.028]^{\star \star \star}$} & {$[0.012]^{\star}$} & [0.013] \\
\hline$(\text { ShortageW })^{\wedge} 2^{\star}$ Pos & -0.136 & & \\
\hline & {$[0.044]^{\star \star \star}$} & & \\
\hline$(\text { ShortageB })^{\wedge} 2$ & 0.002 & 0.177 & -0.022 \\
\hline & {$[0.015]$} & {$[0.031]^{\star \star \star}$} & [0.015] \\
\hline$(\text { ShortageB })^{\wedge} 2^{*}$ Pos & & -0.083 & \\
\hline & & {$[0.047]^{*}$} & \\
\hline$($ ShortageK)^2 & -0.008 & 0.026 & 0.119 \\
\hline & [0.013] & {$[0.011]^{\star \star}$} & {$[0.024]^{\star * *}$} \\
\hline$($ ShortageK)^2*Pos & & & -0.102 \\
\hline & & & {$[0.035]^{\star \star \star}$} \\
\hline$(\text { ShortageW })^{\star}($ ShortageB $)$ & -0.047 & -0.012 & -0.007 \\
\hline & {$[0.015]^{\star \star \star}$} & [0.013] & [0.017] \\
\hline$(\text { ShortageW })^{\star}($ ShortageK $)$ & -0.022 & -0.010 & 0.001 \\
\hline & [0.013] & [0.015] & [0.013] \\
\hline$(\text { ShortageB })^{\star}($ ShortageK $)$ & 0.030 & -0.056 & -0.052 \\
\hline & {$[0.017]^{\star}$} & {$[0.013]^{\star \star \star}$} & {$[0.01193]^{\star \star \star}$} \\
\hline Constant*Tariff & 0.00074 & 0.01419 & 0.002 \\
\hline & {$[0.002]$} & {$[0.002]^{\star \star *}$} & [0.002] \\
\hline Pos Shortage ${ }^{\star}$ Tariff & -0.006 & -0.026 & -0.008 \\
\hline & {$[0.003]^{\star \star}$} & {$[0.002]^{\star \star *}$} & {$[0.002]^{\star \star \star}$} \\
\hline$(\text { ShortageW })^{\wedge} 2^{*}$ Tariff & -0.001 & & \\
\hline & {$[0.001]$} & & \\
\hline$(\text { ShortageW })^{\wedge} 2^{*}$ Pos $^{\star}$ Tariff & 0.002 & & \\
\hline & [0.002] & & \\
\hline$(\text { ShortageB })^{\wedge} 2^{*}$ Tariff & & -0.003 & \\
\hline & & {$[0.001]^{\star \star \star}$} & \\
\hline$(\text { ShortageB })^{\wedge} 2^{*}$ Pos $^{\star}$ Tariff & & 0.002 & \\
\hline & & [0.002] & \\
\hline$(\text { ShortageK })^{\wedge} 2^{\star}$ Tariff & & & 0.001 \\
\hline & & & {$[0.001]^{\star}$} \\
\hline$(\text { ShortageK })^{\wedge} 2^{*}$ Pos $^{\star}$ Tariff & & & -0.000 \\
\hline & & & [0.001] \\
\hline Observations & 4507 & 4507 & 4507 \\
\hline Number of id & 627 & 627 & 627 \\
\hline R-squared & 0.32 & 0.34 & 0.32 \\
\hline $\begin{array}{l}\text { Note: Pos Shortage: Dumn } \\
\text { ShortageK are the shortag } \\
\text { the sector average import } \\
10 \% \text {; }{ }^{\star *} \text { significant at } 5 \% \text {; }\end{array}$ & $\begin{array}{l}\text { Shortage is p } \\
\text { white collar. bl } \\
\text { Standard errors } \\
\text { ificant at } 1 \%\end{array}$ & $\begin{array}{l}\text { sitive. Shorta } \\
\text { le collar and } \\
\text { in brackets. * }\end{array}$ & $\begin{array}{l}\text { N. ShortageB. } \\
\text { ital. Tariff is } \\
\text { unificant at }\end{array}$ \\
\hline
\end{tabular}




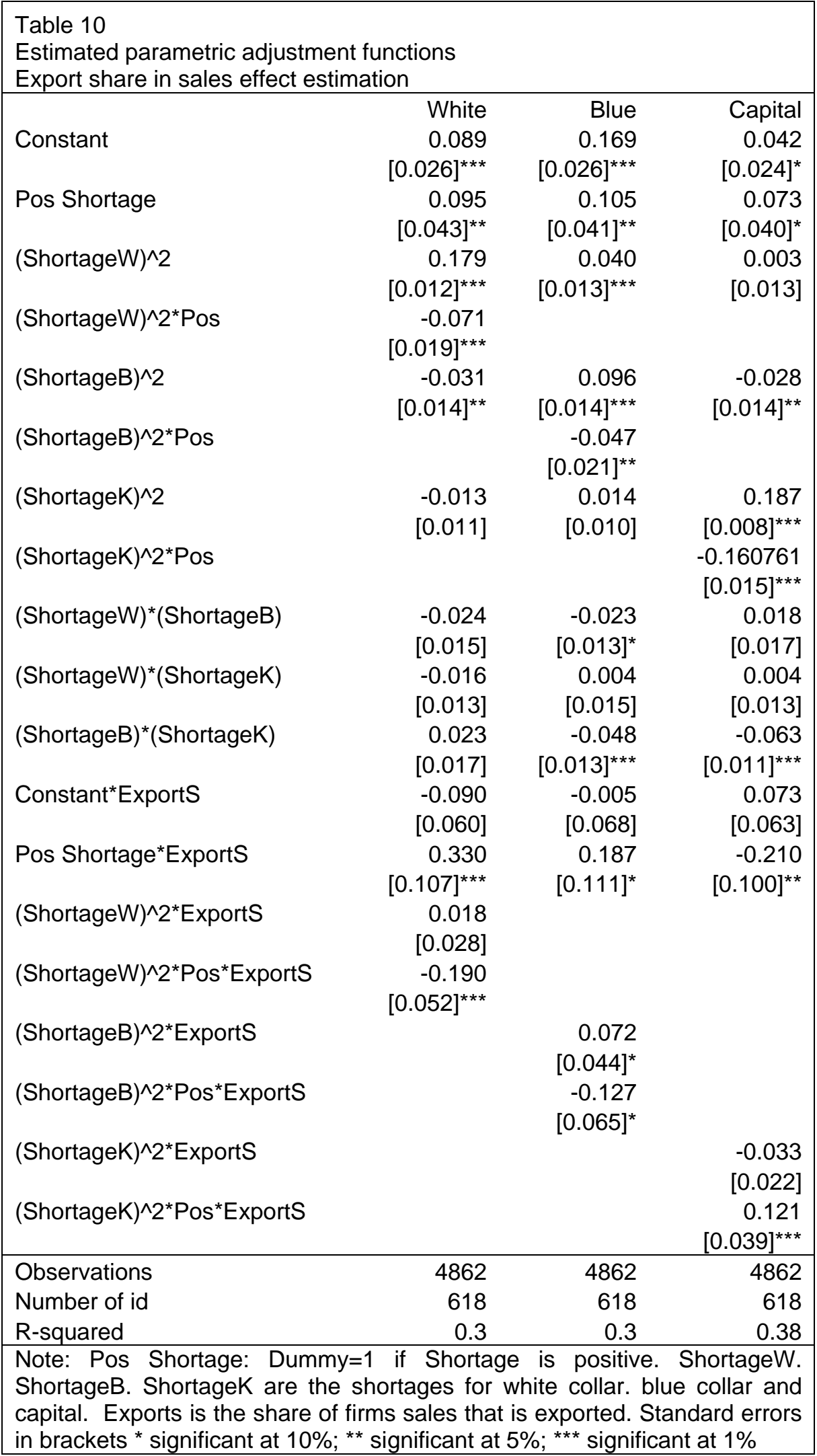


9. Figures

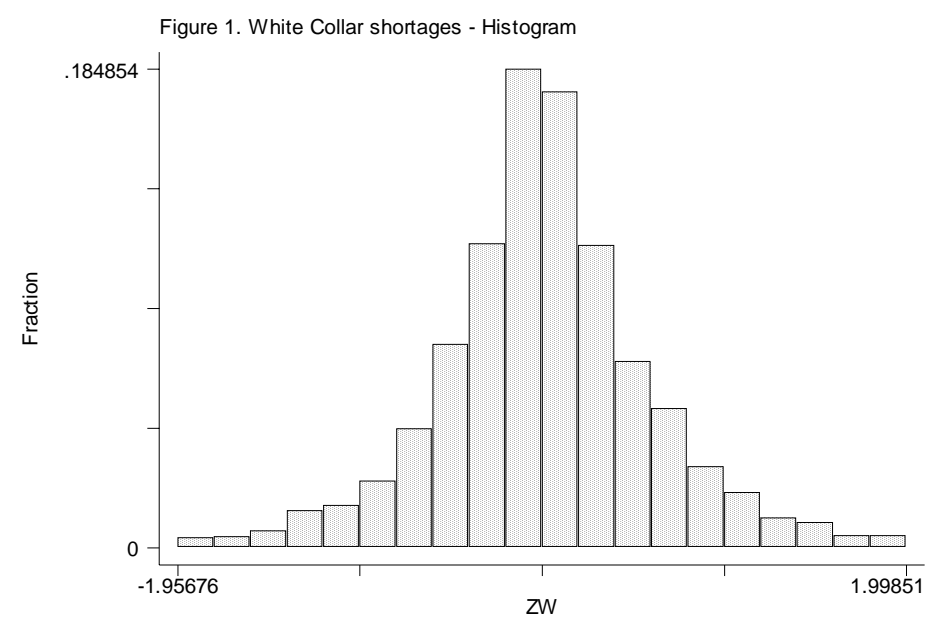

Figure 2. Blue Collar shortages - Histogram

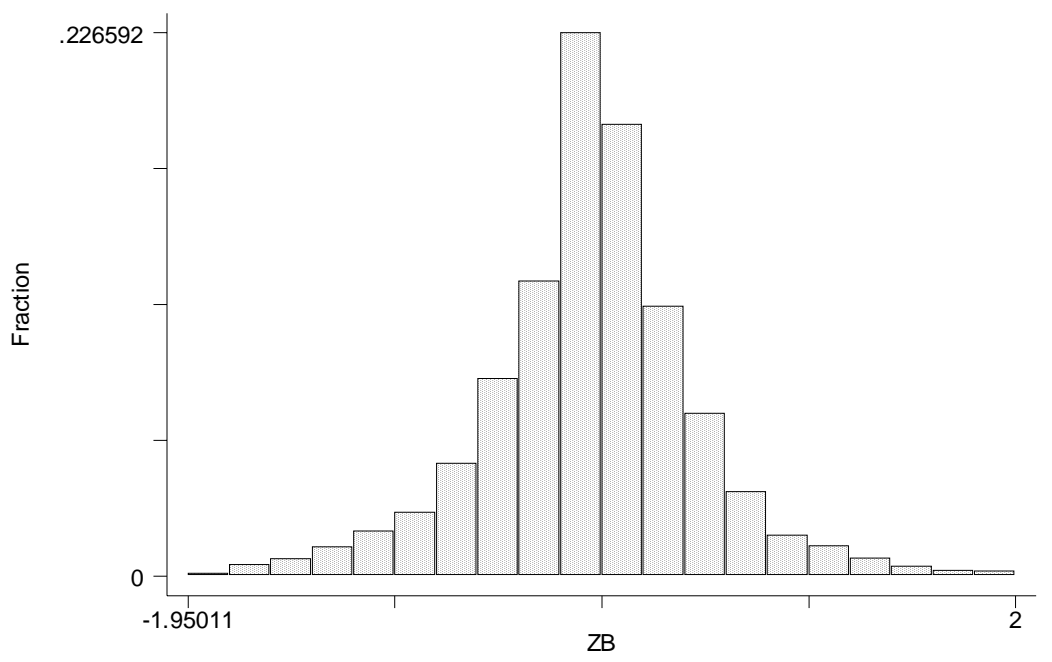

Figure 3. Capital shortages - Histogram

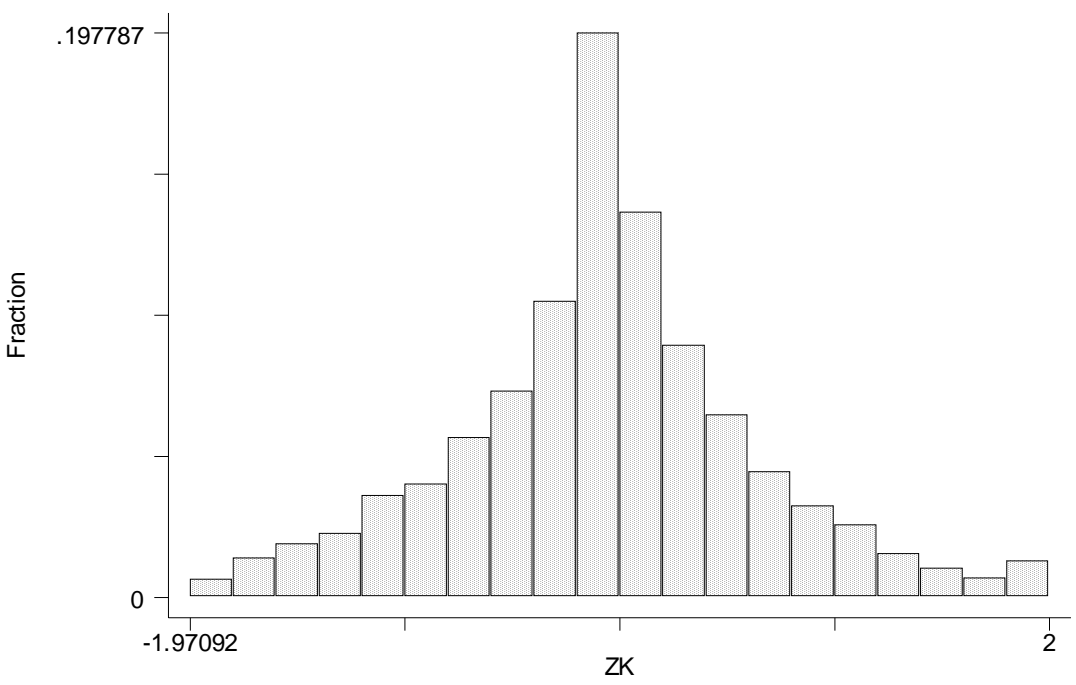



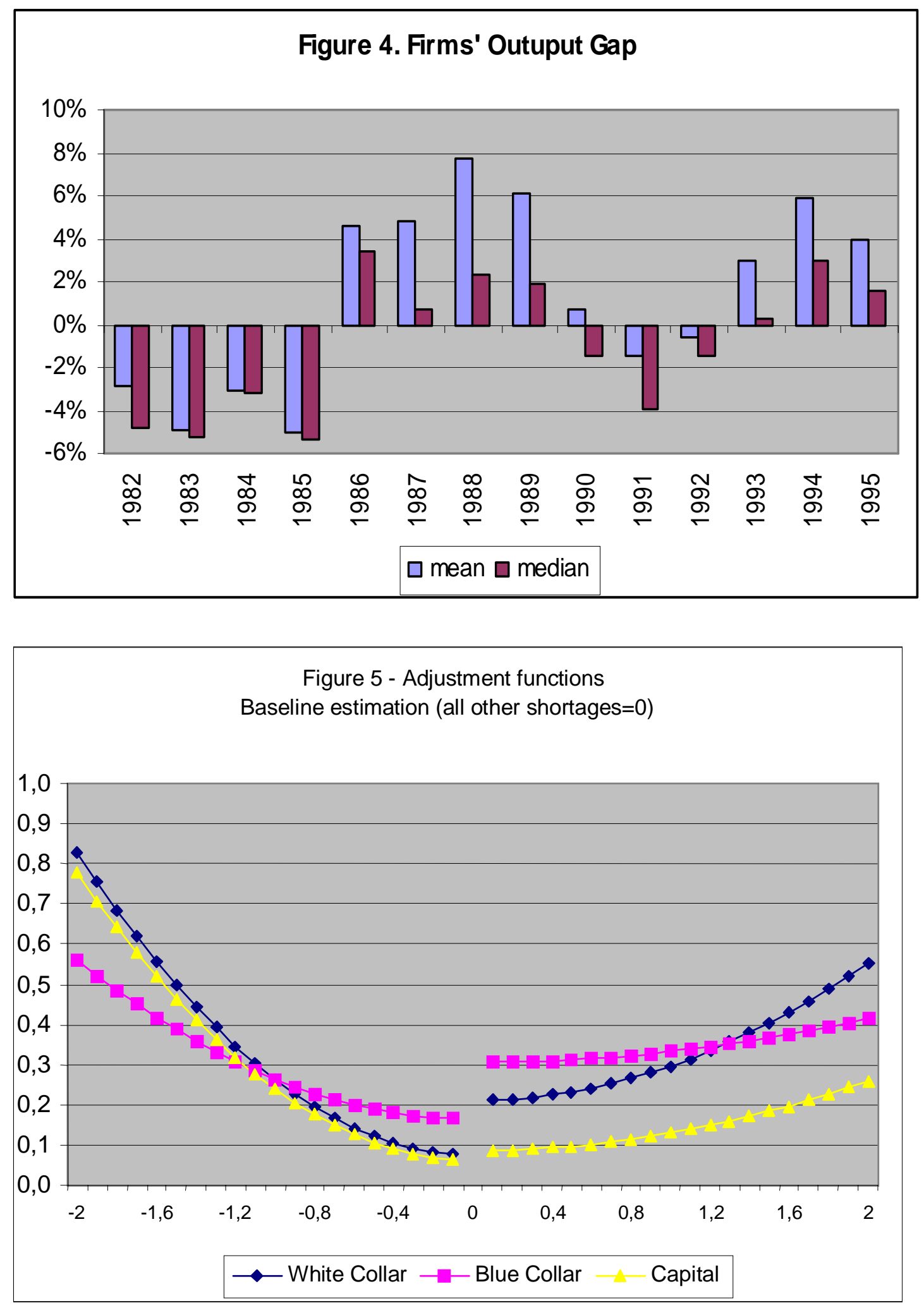

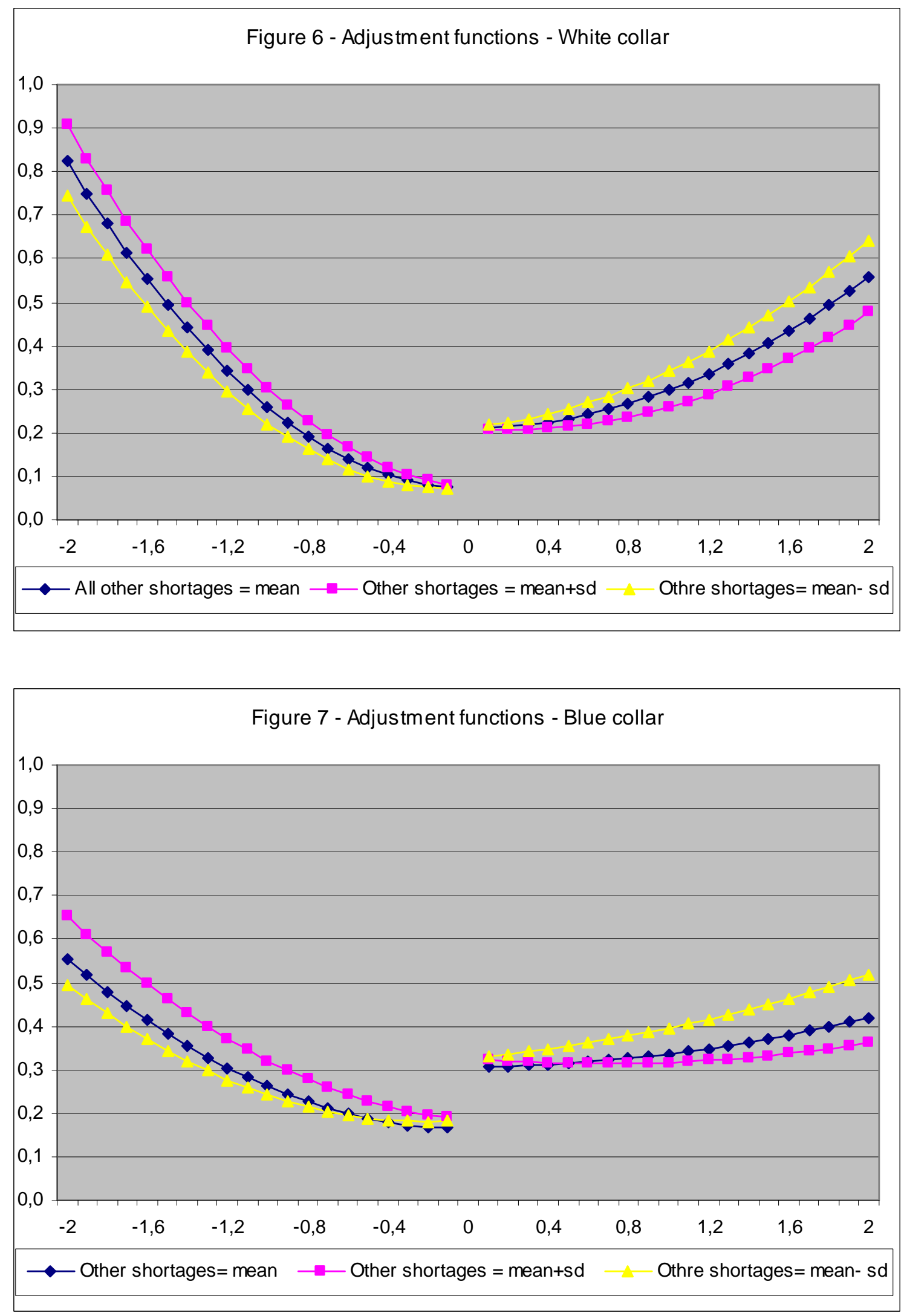

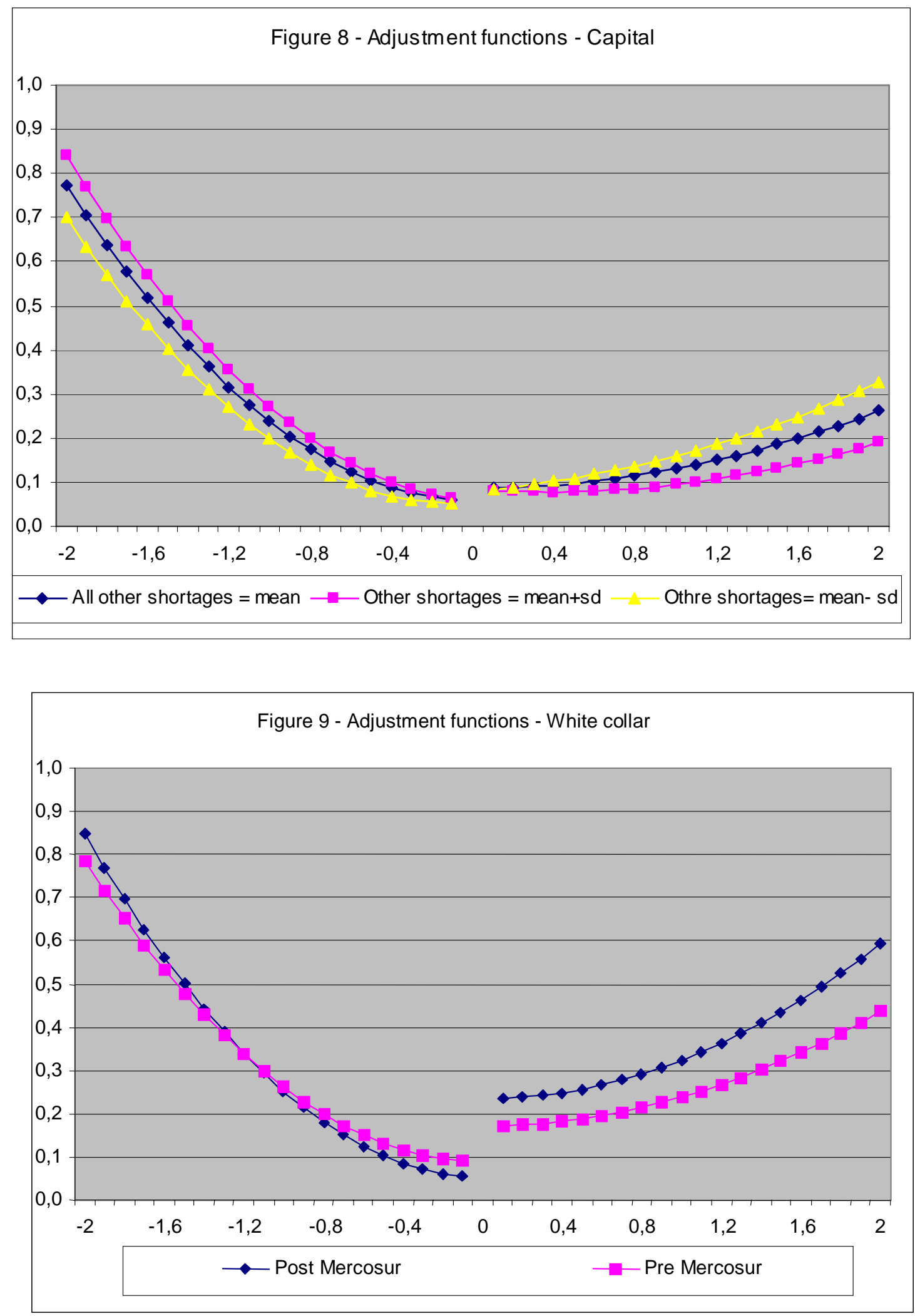

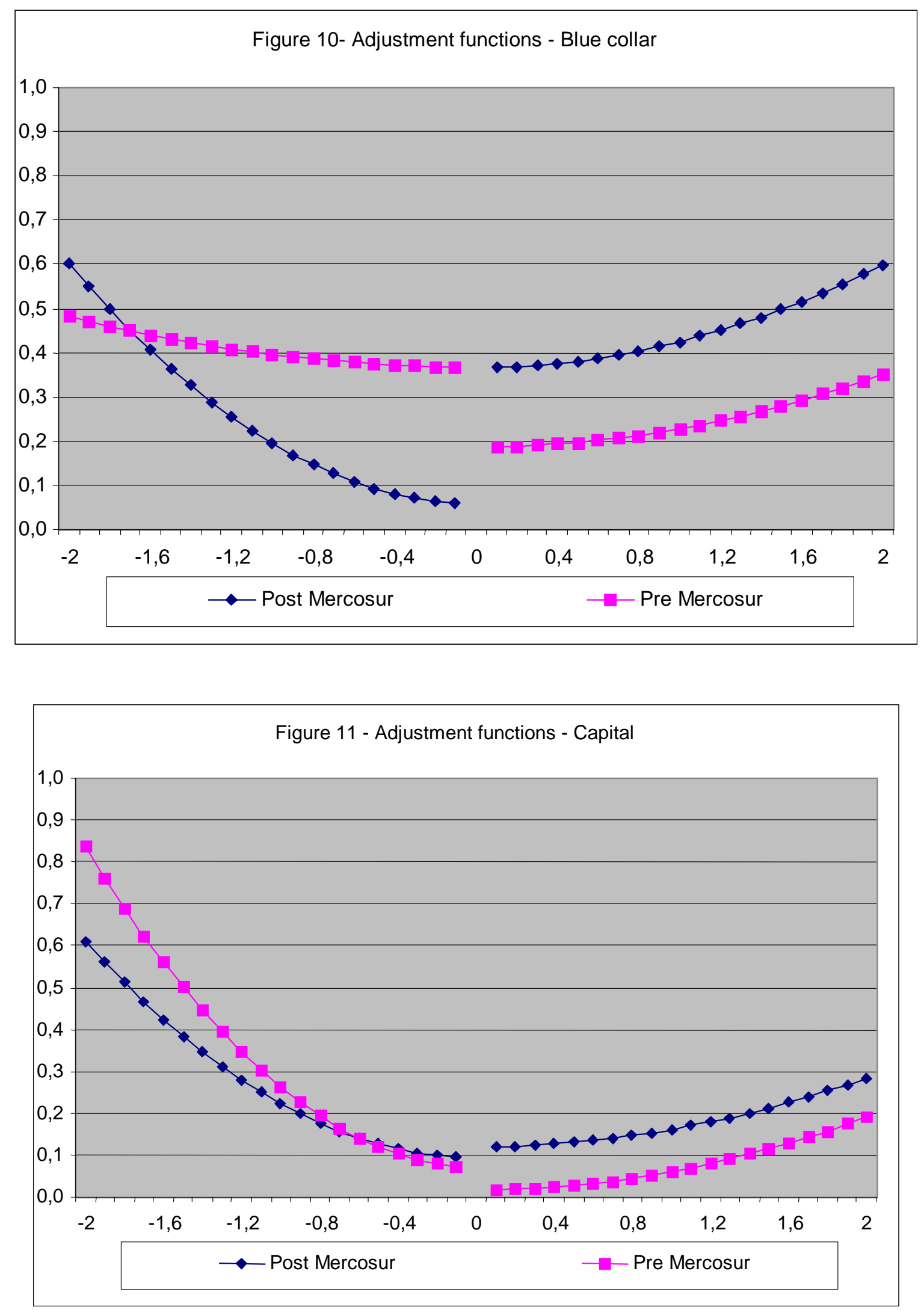

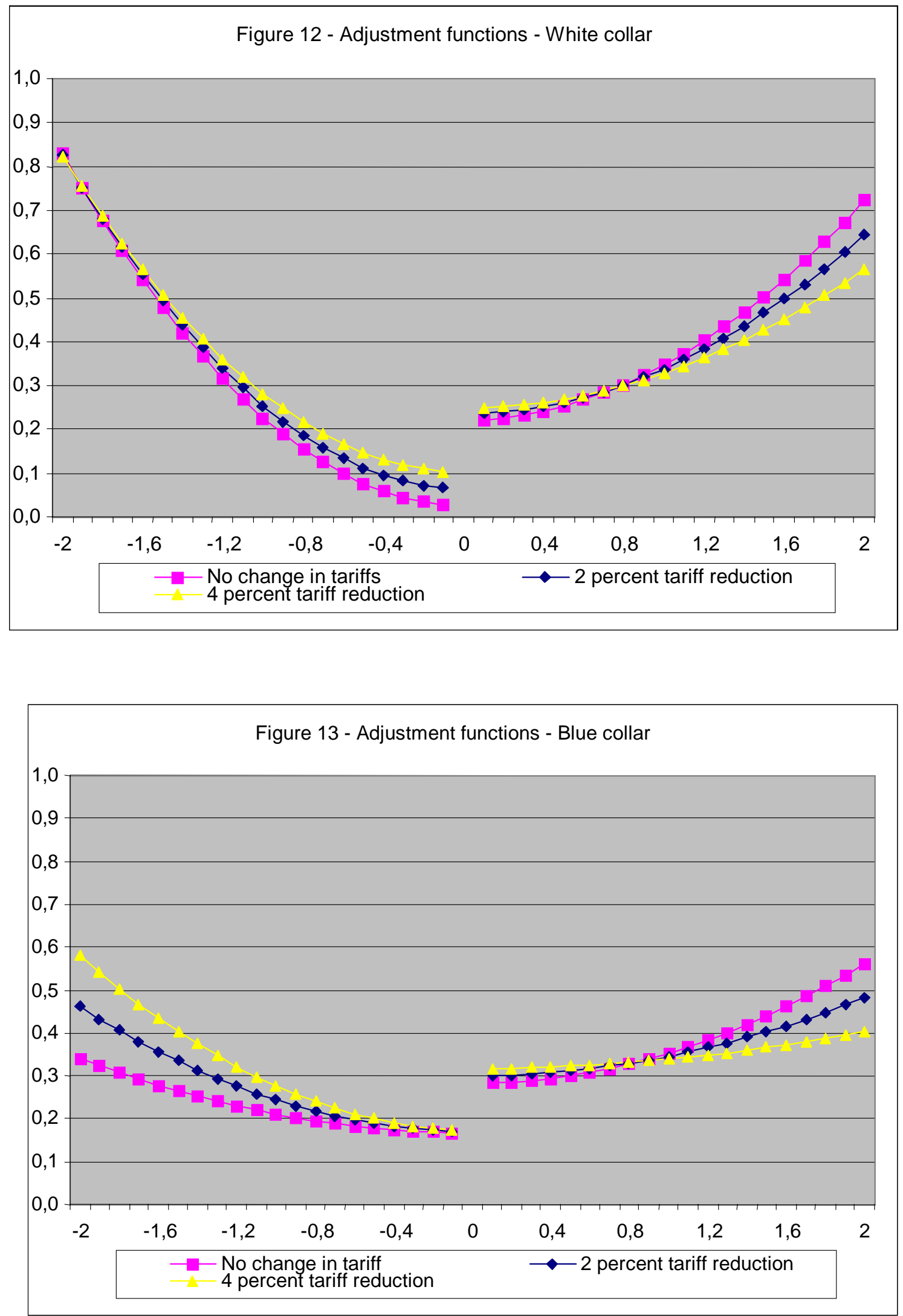

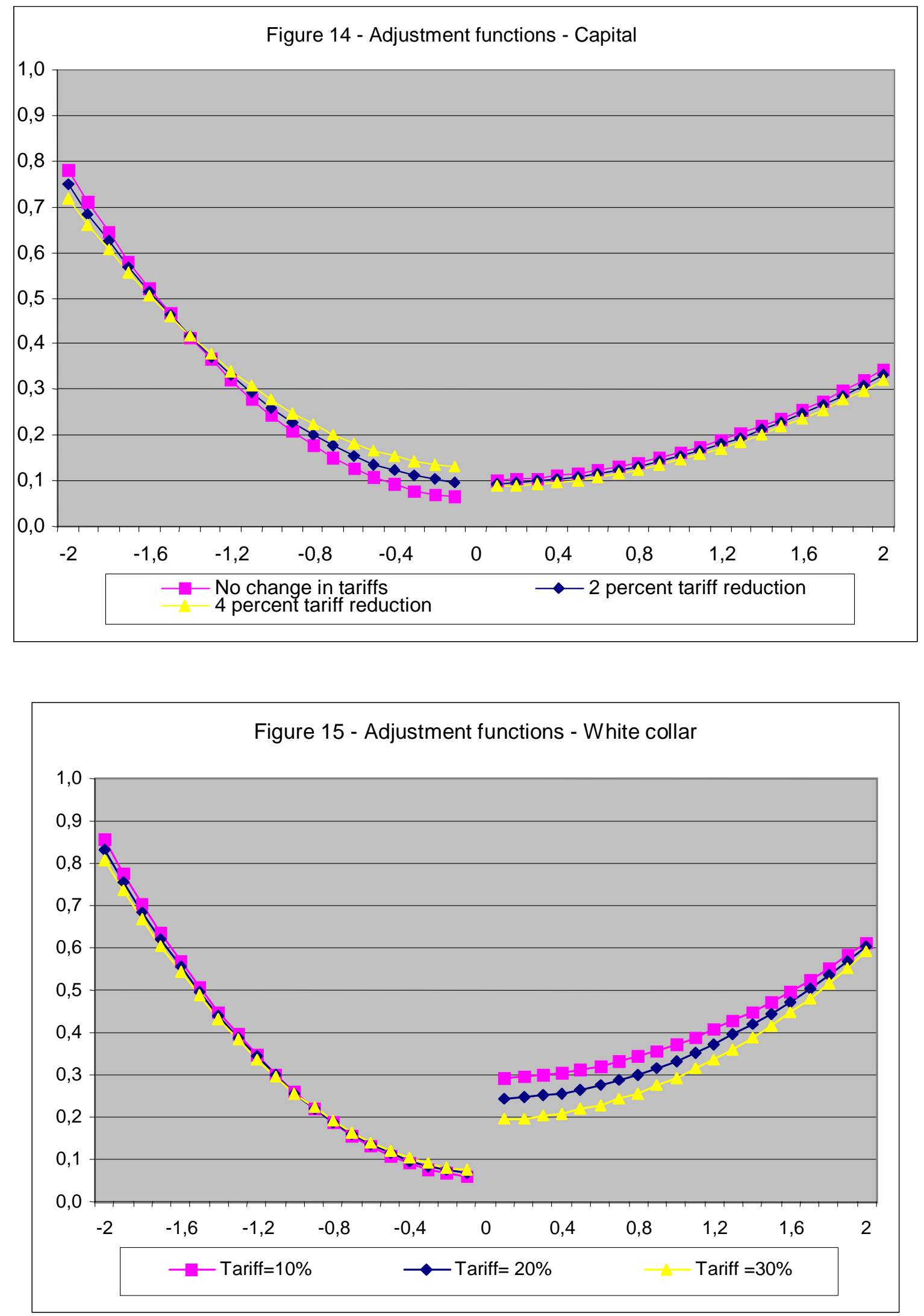

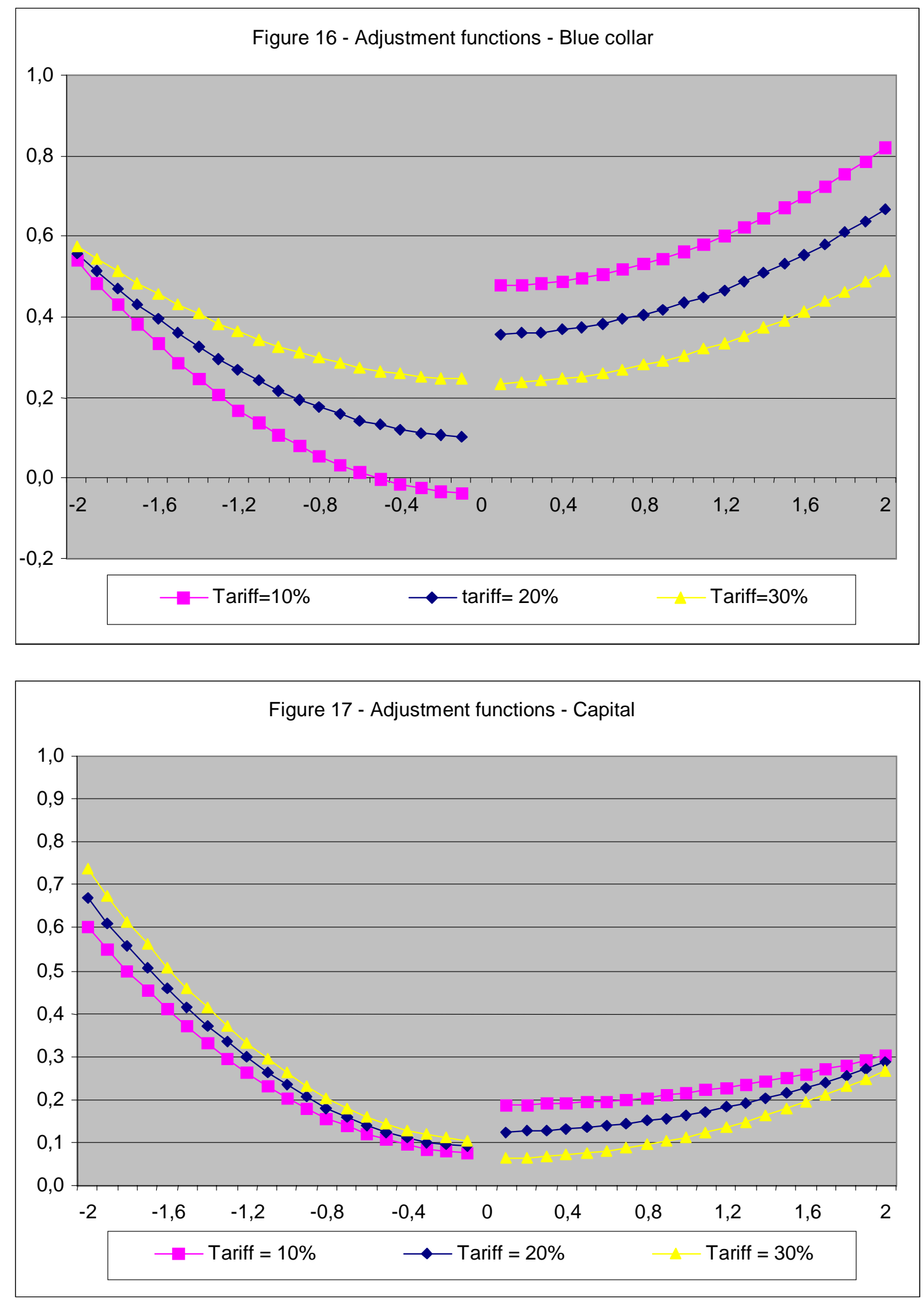

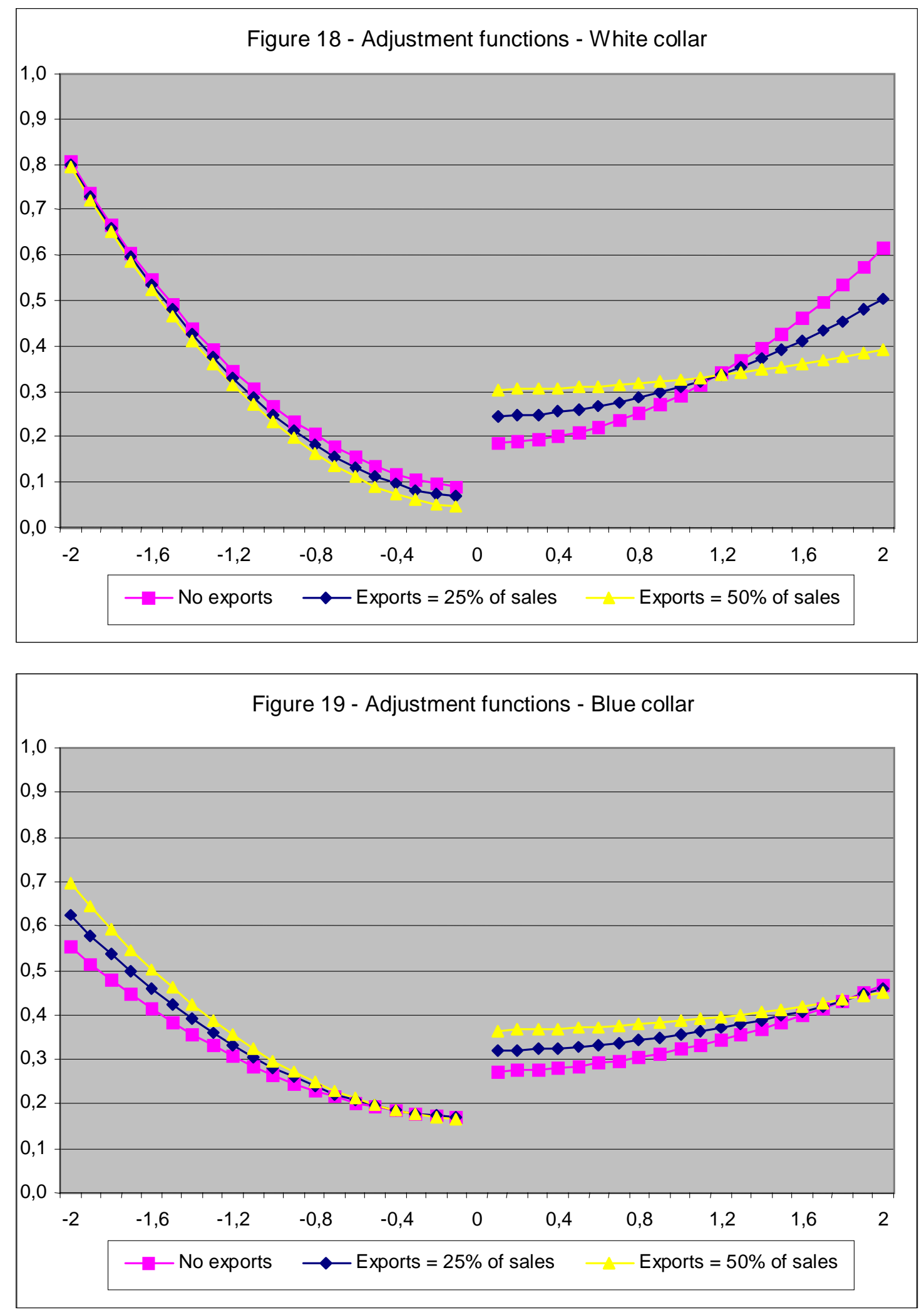


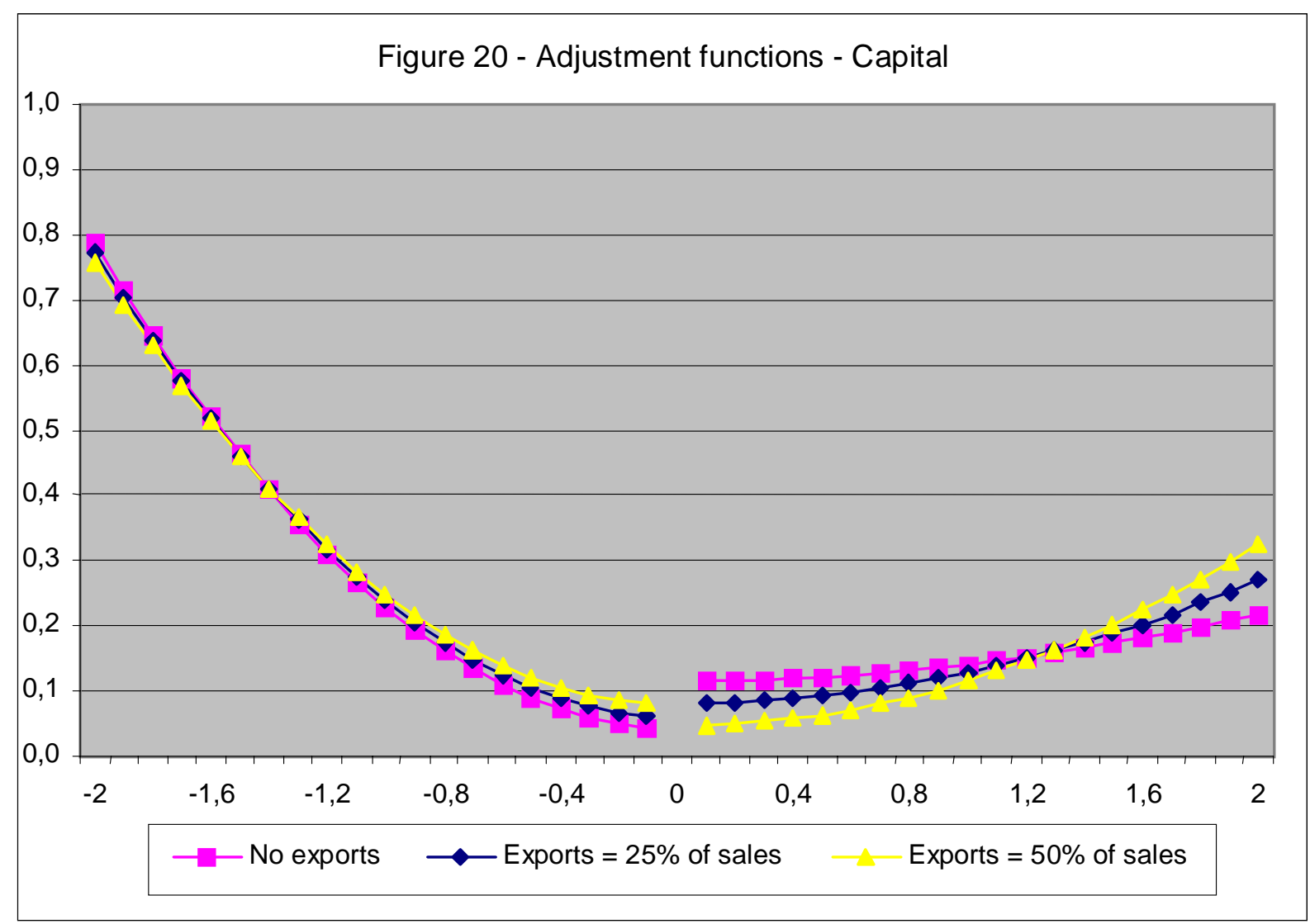

